\title{
Online Discussion Forum Influence on Professional Sport Fan Support: An Exploratory Study
}

MMIM592

\section{VICTORIA UNIVERSITY OF WELLINGTON}

Te Whare Wananga o Te Upoko O te Ika a Maui

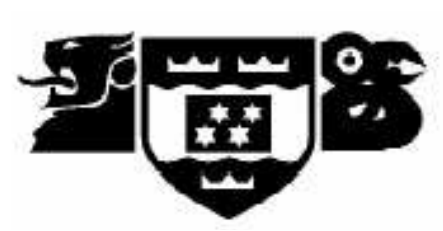

by

\author{
Alexander Natelli \\ Student Number: 300103076 \\ Supervisor: Dr David Pauleen
}

Submitted to the School of Information Management, Victoria University of Wellington

in partial fulfilment of the requirements for the degree of

Master of Information Management

19 September 2008 


\section{Abstract}

With professional sports continually attracting new supporters and these supporters increasingly using Internet technologies, questions arise about the relationship between sport fan online activities and actual fan support for a professional sport team. This paper explores the behaviours and perceptions exhibited by Yellow Fever (online fan site) members as they interact within their online discussion forum. It also studies how these interactions may influence support for the A-League franchise, the Wellington Phoenix football club.

To explore and describe member interactions and opinions, the paper uses a qualitative research approach and data collected from both the forum archives as well as an online questionnaire. The research appears to show that Yellow Fever members do affect fan support for the Wellington Phoenix. It also suggests several ways in which the members can influence fan support. Despite some limitations, there are implications for sporting clubs and technology research. The study also provides a basis for further research both with sport support groups as well as other types of membership dependent organisations such as community projects, local schools and political organisations. 


\section{Table of contents}

Abstract

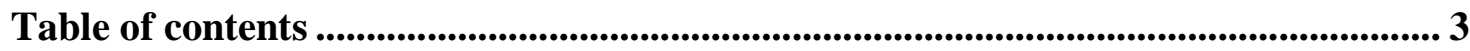

Table of Figures.......................................................................................................................... 4

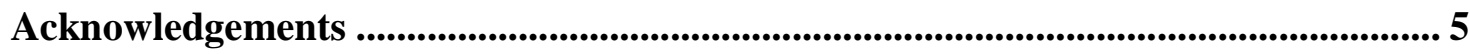

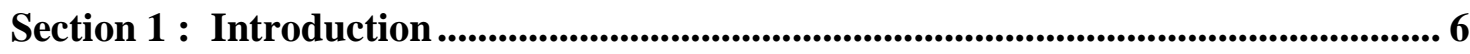

Research Problem ....................................................................................................

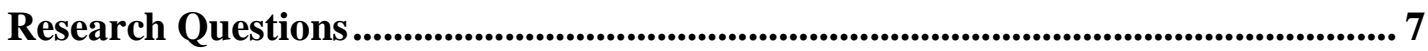

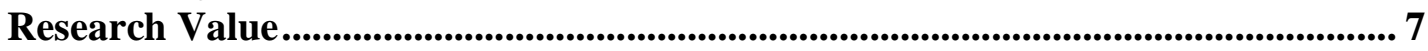

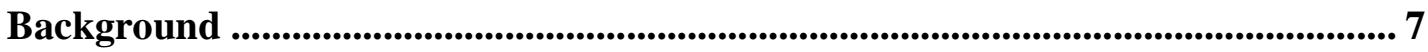

Section 2 : Literature Review.............................................................................................................. 11

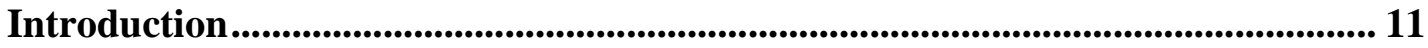

The Emergence of Online Discussion Forums................................................................ 11

Research of Professional Sport ................................................................................ 14

Internet's effect on sport ............................................................................................................. 18

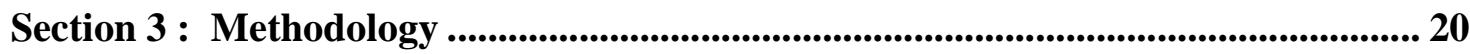

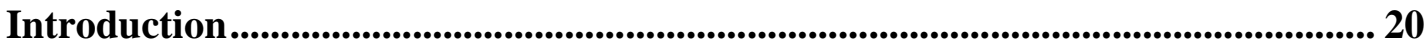

Formulating the Research Questions ..................................................................................... 20

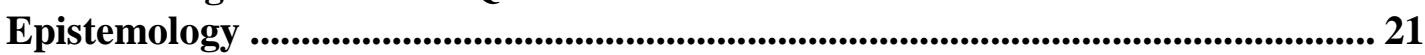

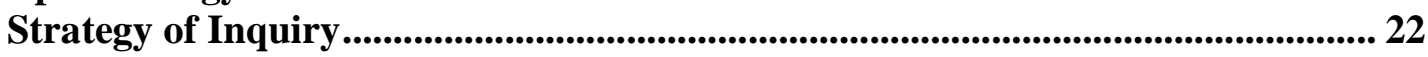

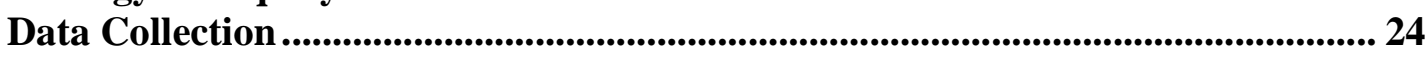

Qualitative Data Analysis............................................................................................. 29

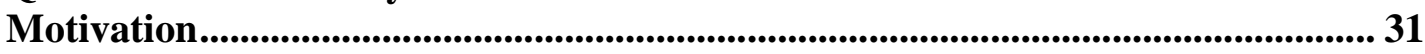

Limitations and Concerns .................................................................................... 31

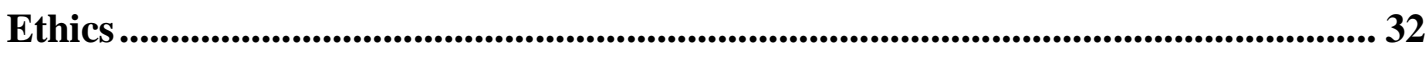

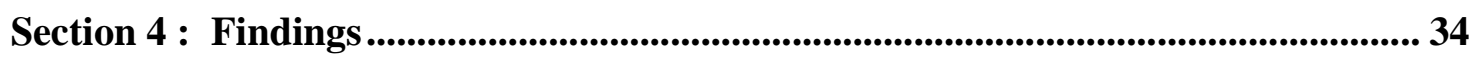

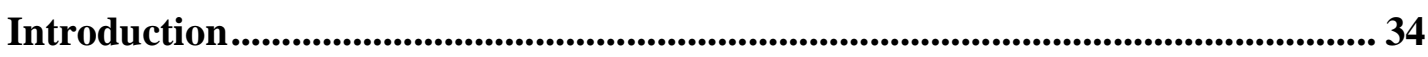

Findings By Month ..................................................................................................................... 34

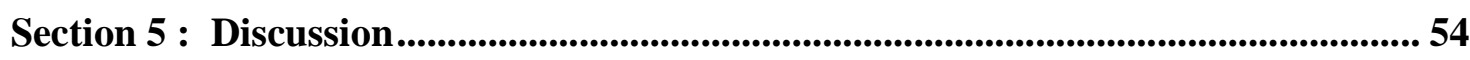

Section 6 : Conclusion....................................................................................................................... 61

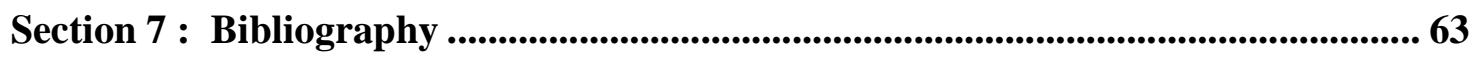

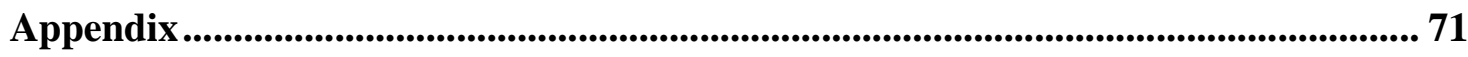




\section{Table of Figures}

Table I - 2007-08 Wellington Phoenix Home Match Results and Attendance, p. 12

Figure I - Example Topic: “Stadium Name”, p. 34

Figure II - Example Topic: "Phoenix kit revealed", p. 34-35

Figure III - Example of Monthly Background, p. 39 


\section{Acknowledgements}

The researcher wishes to acknowledge the following people:

Angela Millar, my partner, for her love and support throughout the process of composing and completing this research study.

Dr. David Pauleen, my research supervisor, for his advice, guidance and patience with every aspect of planning, designing, and writing this research study.

Yellow Fever Site Moderators, for setting up the website, allowing me to use the discussion forum archives and for encouraging members to participate in the online questionnaire.

Yellow Fever Members, for providing your thoughts and opinions to this research. Also, for your passion and commitment toward driving the Wellington Phoenix to success. 


\section{Section 1: Introduction}

\section{Research Problem}

Many acknowledge the Internet as a significant factor for societal change (Beech, Chadwick \& Tapp, 2000). People are increasingly using Internet technologies to communicate with colleagues, customers, friends, family and others (Nicolopoulou, Kostomaj \& Campos, 2006). As professional sports continue to attract an ever-increasing number of supporters (Mason, 1999; Pons, Mourali \& Nyeck, 2006) and these supporters increasingly use Internet technologies, questions arise with regard to the connection between these technologies and their influence on sport.

The purpose of this paper is to explore a relatively overlooked research gap between the use of the Internet and support of professional sport teams. Despite conducting an extensive search of the literature, the researcher was unable to find research which delved into how online discussion forums influence the consumption of sport products and services. Considering the prominence of both the Internet and professional sports, this is a surprise (Miller, Lawrence, McKay \& Rowe, 2001). The lack of both a theoretical and empirical base signifies challenges for discovering and defining the unknown variables.

The central issues of this research paper involve the behaviours and perceptions exhibited by the participants in an online discussion forum, and whether or not their online activities translate in off-line support for a professional team. With the emergence of the Wellington Phoenix Football Club (Patterson, 2008), it appears that New Zealand sport fan interest has also increased. Moreover, a local Wellington Phoenix support group launched a 
website that includes online discussion forums (Know your fever, n.d.). The following research questions arise from this situation.

\section{Research Questions}

1. Does participation in the Yellow Fever online discussion forum influence fan support for the Wellington Phoenix Football Club?

2. If so, in what ways do the Yellow Fever members impact fan support for the Wellington Phoenix?

\section{Research Value}

This research has implications for organisations that rely on membership support. The researcher expects that sport managers and researchers will broaden their work to include the impacts and opportunities of online group interactions. Similarly, it is anticipated that information services researchers will expand their work to include the sports and leisure industry.

\section{Background}

Traditionally overshadowed by Rugby Union, New Zealand Football achieved a surge in media and spectator attention in 2007. Ever since the New Zealand Rugby Union's tour of Great Britain in 1905, rugby has dominated as the premier sport (Scherer, Falcous, \& Jackson, 2008). Although a part of New Zealand life since the 1880's, football received 
little mainstream notice until the national team qualified and participated in the Fédération Internationale de Football Association (FIFA) World Cup of 1982 (Popular Culture, n.d.).

Unable to maintain this momentum, New Zealand Football experienced a series of financial challenges and lost its brief resurgence (Kennedy, 1995). Foster (2006) describes two example failures. The first involves the Australian National Soccer League (ANSL) franchise, the New Zealand Football Kingz, who joined in 1999 but dissolved after five disastrous seasons. As the ANSL was revamped into the A-League in 2005, The Kingz received additional funds which saved the franchise. The second failure relates to the continued financial and sporting disappointment by the New Zealand Knights. After changing their name and logo and two seasons of poor results, the Football Federation Australia (FFA) revoked their license to participate in the A-League (Dixon, 2007; “Knights Have Licence Revoked By Soccer Body", 2006). With accumulated losses amounting to A $\$ 16$ million, the A-League decided to cut the Knights who could only average 3,745 spectators per match (Stewart, 2007).

Learning from the failed experiences of the Football Kingz and New Zealand Knights, Terry Serepisos put together the Wellington Phoenix franchise by investing \$6 million in his 100 percent ownership (Patterson, 2008). He then negotiated a sponsorship agreement with global electronics giant Sony in November 2007 (“Stop Press," 2007, p. 1-4). The resulting inaugural season produced an amazing 11,394 spectators per match (see Table I) average (What's been on at the stadium, n.d.). This resurrection in New Zealand football interest marks a change worthy of academic attention. 
Table I - 2007-08 Wellington Phoenix Home Match Results and Attendance

\begin{tabular}{lllr}
\hline \multicolumn{1}{c}{ Date } & \multicolumn{1}{c}{ Opponent } & \multicolumn{1}{c}{ Result } & Attendance \\
26 August 2007 & Melbourne Victory FC & Draw 2-2 & 14,177 \\
9 September 2007 & Newcastle Jets FC & Loss 0-1 & 10,800 \\
22 September 2007 & Adelaide United FC & Draw 2-2 & 11,528 \\
30 September 2007 & Perth Glory FC & Win 4-1 & 9,358 \\
21 October 2007 & Central Coast Mariners FC & Loss 1-2 & 9,586 \\
17 November 2007 & Sydney FC & Draw 1-1 & 7,041 \\
30 November 2007 & Adelaide United FC & Loss 1-2 & 18,229 \\
1 December 2007 & Los Angeles Galaxy (non-league game) & Loss & 31,853 \\
7 December 2007 & Perth Glory FC & Win 3-0 & 6,188 \\
14 December 2007 & Queensland Roar FC & Draw 1-1 & 7,333 \\
4 January 2008 & Sydney FC & Loss 0-2 & 13,065 \\
& Results: & 2 Wins, 4 Draws & 139,158 \\
\hline
\end{tabular}

Sources: Wellington Phoenix (n.d.); \& What's been on at the Stadium. (n.d.).

This research paper notes the establishment of an independently-run supporters group, the Yellow Fever (Know your fever, n.d.), and its use of new technologies as a parallel development. Although, the Kingz and Knights enjoyed the support of their own supporters group, Bloc 5, it appeared to have little impact on woeful attendance figures (Bloc 5, n.d.). Despite several years of work, the North Harbour Stadium-based group was only ever able to achieve a peak membership of 300 ("Avid supporters still produce a great song and dance”, 2006) along with the previously stated home attendance averages. 
In contrast, the Yellow Fever (http://www.yellowfever.co.nz) blended the use of timely team news with the introduction of online discussion forums. These forums facilitate online interaction between Yellow Fever members and may have allowed an online community to form (Parr \& Ward, 2006).

The next section consists of a literature review which explores previous research in the areas of the Internet, sport and the impact of the Internet on sport. This is followed by sections on methodology, findings, discussion and conclusion. 


\section{Section 2: Literature Review}

\section{Introduction}

The task of conducting a literature review provides the researcher with the opportunity to understand what work has already been done on a topic, how that research was conducted and some insight into the key issues (Hart, 1998). This section represents an extensive search of online discussion forums, sports research and connection between Internet technology and professional sport fan support.

\section{The Emergence of Online Discussion Forums}

The promise of improved communications between geographically dispersed groups of people is the most salient quality of Internet technologies (Wilson \& Peterson, 2002; Beuchot \& Bullen, 2005). This prompted research into the reasons for this phenomenon. Parameswaran and Whinston (2007) note several factors for the proliferation of online groups, including shared interests, increased computer power, lower costs, faster networks and advances in content publishing tools. Online interactions vary according to group interests, topics, communication methods and number of people (Millen \& Dray, 2000; Wilson \& Peterson, 2002). The types of online groups can be categorised according to whether they function synchronously or asynchronously (Rosenberg, 2004).

Synchronous communication involves rapid interaction between individuals, which is often less structured than asynchronous communications (Marra, 2006). When online groups communicate synchronously, or in real-time, they typically communicate via chat 
rooms, instant messaging and web conferencing (Rosenberg, 2004). Chat rooms are software enabled virtual rooms where typed messages are visible to everyone attending that space (Primeaux \& Flint, 2004). Instant messaging (IM) represents a similar set of functions plus contact lists and contact status messages (Cao \& Everard, 2008). Web conferencing entails web-based exchange of real-time voice, text and video (Campbell, 1997).

Asynchronous communication tools introduce delays between interactions which appear to assist the participants add structure to the interaction (Marra, 2006). Examples include electronic mailing lists, online discussion forums and wikis. Electronic mailing lists, or listservs, distribute messages and information to other members via email accounts (Morville, Rosenfeld, Janes, DeCandido, 1999). Dern (1994) and Rosenberg (2004) argue that user access is constrained when using this method. Rosenberg notes that since electronic mail lists do not include a central message repository, members cannot search past messages for relevant information. Another asynchronous communication tool is the wiki. Wikis are interactive websites that allow members to create, edit, and delete content with minimal web editing skills (Raman, 2006). Although wikis are easy to use, members typically apply some governance to content placement, topic reviews and validation processes (Chisholm, 2007). A third type of asynchronous communication is the online discussion forum. Sometimes referred to as bulletin boards or newsgroups, online discussion forums allow individuals to interact via messages on a shared website (Cothrel, 2000; Nicolopoulou, et al., 2006; \& Shaul, 2007). Most of these posted messages are visible to all members, which allow them to respond or add new messages (Flor, 2006; 
Pappas, 2002; Rosenberg 2004). An important aspect of online discussion forums is that it is difficult to ascertain member affiliations off-line or in other online groups.

The topic of online discussion forums has attracted substantial research interest (Millen \& Dray, 2000). According to Farquhar and Rowley (2006), significant work has been done in the context of education, learning, knowledge management, organisational development and supplier networks. Bickart and Schindler (2001) research the connections between participation in online discussion groups and electronic commerce activities. They found that consumers who gathered product information from online discussion forums were markedly more interested than participants asked to gather information from corporate websites. They attribute this to the presence of personal experiences, a perceived greater credibility and content that appears more relevant to consumers. Moore and Marra (2005) investigate the impact of these online technologies on education and learning. They compared rates and types of participation by conducting a content analysis model on two student groups. Cothrel (2000) studied the dynamics in which online community sponsor attain value for their funding. He presents three ways for measuring online community value. The first is the additional value that a business achieves that can be attributed to the online forum. The second relates to the size of the membership. The third involves the conversion of visiting members to purchasing members. Wilson and Peterson (2002) focus on the cultural themes of online communities. They conclude that these new technological methods are also cultural products. Beuchot and Bullen (2005) cite examples of research which considers the social dimensions of online communication and their impact on the quality of interaction. 
Although online communities share some of the same characteristics as real world communities (Parr \& Ward, 2006), membership and participation variables make online groups difficult to study (Wilson \& Peterson, 2002). Wilson and Peterson assert that online identities are easily disguised or multiplied such that members can maintain their anonymity for the most part. Beech, et al. (2000) study the passive members. They use the analogy of a "flea market" to emphasise the greater proportion of passive browsers rather than active participants. Little research has been done on these non-participating "lurkers" even if the make up a large portion of community members (Beech, et al., 2000; Nonnecke, Andrews \& Preece, 2006). Moreover, there is some debate about the nature of these groups. For example, Parameswaran and Whinston (2007) claim that since interactions within these groups tend to be anonymous, it follows that the relationships between users are weak. Farquhar and Rowley (2006) argue that online community members share common bonds. Likewise, Beuchot and Bullen (2005) examine the concepts of interpersonality and social presence, and mention numerous examples of studies that contradict the notion of online discussion groups cannot cultivate close relationships between users.

\section{Research of Professional Sport}

When researchers do examine professional sport, they appear to focus on sports management, marketing and on-field performance (Dale, van Iwaarden, van der Wiele \& Williams, 2005; Espitin-Escuer \& Garcia-Cebrian, 2006; Greenwell, Fink \& Pastore, 2002; \& Theodorakis, Kambitsis, Laios \& Koustelios, 2001). Further exploration of fan 
support would appear to require an examination of what constitutes a sport product, the types of spectators and any other business concerns.

According to Shank (1999), a sport product is a good, a service or a combination of the two created to benefit sport spectators, participants or sponsors. There are two components of the professional sport product (Theodorakis, et al., 2001). The first component includes all aspects of the actual event (Shank, 1999; Theodorakis, et al., 2001; Greenwell, et al., 2002). The second component, or "extension products", comprises all other services related to the event (Theodorakis, et al., 2001; Dale, et al., 2005). Examples of extension products include ticketing, food and beverage and car parking (Westerbeek, Smith, Turner, Emery, Green \& van Leeuwen, 2005). Fullerton and Merz (2008) define the sports product as the sale of access to sporting events. This is reasonably close to the previously described event component. Interestingly, they also assert that that access is valueless without the competition on the sports ground.

Sport holds an important role in modern society (Shank, 1999). According to Frey and Eitzen (1991), almost every society holds sport in a very prominent social position. Spectators and sponsors look to sport for entertainment, distraction from daily issues or business opportunities (Westerbeek, et al., 2005). Mason (1999) states these sport consumers are comprised of individual fans, local communities, corporate sponsors, television media and other media. According to Thwaites (1999), a general growth in 
discretionary income has provided consumers with greater opportunity and choice for leisure activities.

However, many sports are experiencing increased competition from other sports as well as other leisure options (Shilbury, Quick, \& Westerbeek, 2003; Snipes \& Ingram, 2007). In Australia and New Zealand, commercial activity associated with professional sport represents approximately A $\$ 1.3$ billion (Hoyle, 2005). The competition between major sport codes, including Rugby Union, Rugby League and Soccer, is increasing (McKewen, 2008). These codes are competing for media budgets, corporate sponsorships and spectator attendance.

Considering the importance of sport to society and the competition between professional sport codes, understanding what influences spectator attendance is important. Snipes and Ingram (2007) cite that all sport organisations aspire to maximise fan attendance as a means to creating an attractive atmosphere. This is supported by Madrigal (2006) when he asserts that the presence of spectators actually enhances a sporting event. Snipes and Ingram (2007) assert that spectator attendance may be more affected by a team's ability to entertain, than their winning record. Fans attend for a variety of reasons including camaraderie (Westerbeek, et al. 2005), diversion, entertainment, eustress, and family ties (Shank, 1999). Dale, et al. (2005) describe two broad categories related to sport attendance research. The first examines quantitative factors related to perceived attendance factors, and the second studies qualitative factors such as fan attitudes and behaviours. Shank (1999) opines that attendance can by defined by controllable and uncontrollable economic factors, which include ticket pricing and the perceived value of 
the sport product. Coats and Humphreys (2007) report evidence that professional sport attendance is rigidly tied to ticket prices, which contradicts the idea that sport franchises can practice monopolist pricing within their regions. Snipes and Ingram (2007) differentiate a wider set of categories, which include game attractiveness, economic factors, demographic factors, promotional factors, scheduling and venue preferences, and intrapersonal factors. Game attractiveness refers to the perceived quality of an event, the skill level of participants, team records and historical rivalries (Shank, 1999). The uncertainty of the outcome appears to be particularly important to this factor (Mason, 1999). Spectators witness the action, and deepen the emotional tension (Madrigal, 2006). Furthermore, some researchers highlight the importance of stadium access, aesthetics, cleanliness, location, parking facilities and seat comfort (Shank, 1999; Westerbeek, et al., 2005). Although it appears that many of these factors could easily apply to other leisure activities, such as the performing arts, it seems that the uncertainty of the outcome distinguishes sport from other forms of entertainment.

Smith and Wheeler (2002) explore loyalty and the emotional connections required for people to affiliate with an organisation or product. They state that customer satisfaction is no longer sufficient for market leader. Additionally, they suggest that organisations can benefit from activities that cause customers to advocate on behalf of the organisation. Murrell and Dietz (1992) report on previous research which shows a connection between fan support of a sport team and overall team success. They argue that fan identification may operate independently of actual attendance, and therefore be a better determinant of fan support. Fisher and Wakefield (1998) also find that a strong identification with a 
group supports consumption behaviours. The researcher notes that spectator identification with the Wellington Phoenix is potentially more important than attendance when evaluating fan support.

The literature mentions television, radio and other media options as competitors to game attendance (Mason, 1999; Shank, 1999). However, it also suggests that the negative impact on gate revenues is probably offset by television and sponsorship revenues (Shilbury, et al., 2003). These points may relate well to the revenue concerns, but they do not appear to cover the topic of game attractiveness. It is possible for teams to succeed commercially in the short term at the expense of game attractiveness and long term revenues.

\section{Internet's effect on sport}

Although a search of the literature reveals some sports related articles, only one of those papers investigates the Internet's effect on sport clubs. Beech, et al. (2000) report four significant findings. The first is that despite the lack of academic interest, English football club managers viewed the Internet as an important revenue source and community builder. Secondly, Beech et al. believe that there was an especially rapid adoption of Internet technology by the leisure and sport sector as a whole. A third point is that although the football clubs had a variety of objectives for their websites, they were able to group them into two categories: "transaction" and "relationship". Some of the football clubs clearly had a preference for short-term, transactional online activity, which appears to inadvertently conflict with their interest in building a consumer community (Farquhar 
\& Rowley, 2006). That is they spent their resources on short-term, transactional objectives at the expense of activities that could promote community growth. Lastly, the researchers affirm that the Internet was not a replacement for more traditional marketing channels; rather it appears to be a new channel and an appropriate part of the football clubs' communications mix. Wilson and Peterson (2002) state the need for balanced research in terms of online and real-world interactions.

The next section comprises a discussion of the methodology used to formulate the research as well as collect and analyse the data. 


\section{Section 3: Methodology}

\section{Introduction}

This section introduces and explains the methodological philosophy behind this research paper. It starts with an examination of the epistemology which guides the research. After a discussion on the strategy of inquiry, the section then describes the selected methodology which includes sections on data collection and data analysis strategies. Lastly, limitations and concerns are clarified in terms of the stated research objectives.

\section{Formulating the Research Questions}

The researcher encountered several challenges associated with formulating research questions for this study. Having visited the Yellow Fever website for information on the Wellington Phoenix football club, the researcher noticed a substantial amount of online interactions within the discussion forums. A question arose concerning the connection between the success of the forum and the success of the team. As observed in the preliminary literature review, very little research had been done in this area. After a discussion with colleagues, it was decided that the success of the online discussion forum would be measured with a mixture of quantitative and qualitative measures. The team success measures would include revenue, attendance and win-loss record. Shortly thereafter, it became apparent that the team financial information was not available, which severely limited the research (Creswell, 2003). As well, the researcher realised that there were too many other factors to conduct an explanation of the phenomena. These factors include the novelty of having a professional football team in Wellington, fans, players, 
management and ownership. The lack of literature on a connection between Internet technology and professional sport favours exploratory research, which seeks to describe and fact-find, rather than explain phenomena (King, Keohane \& Verba, 1994). With further review of the literature, the researcher discovered the concepts of fan support (Murrell \& Dietz, 1992) and its impact on fan behaviour (Fisher \& Wakefield, 1998). Thus, the research was framed around Yellow Fever online discussion participation and possible types of influence on fan support behaviours.

\section{Epistemology}

The purpose of conducting research is to gain knowledge. Part of that process involves the realisation that researchers work within the confines of their own beliefs, experiences and perspectives (Guba \& Lincoln, 1994). Epistemology refers to the study of knowledge (Cunningham \& Fitzgerald, 1996). The definition includes assumptions about knowledge and how it can be attained (Myers, 1997). Understanding these guiding beliefs can assist researchers in conducting their work (Cunningham \& Fitzgerald, 1996). According to Myers (1997), the classification of epistemology types vary, and he cautions that these categories are not always as clear and distinct as the proponents would argue. Orlikowski and Baroudi (1991) claim three categories: positivist, interpretive and critical. Positivist research is said to be conducted with an assumption that reality is always objective and measurable. These researchers generally seek to increase the predictive understanding of phenomena by quantitatively testing existing theory. Orlikowski and Baroudi describe interpretive research as attempting to understand the world through the language and shared meanings that people apply to phenomena. Proponents of critical research 
generally assume that social reality is based on historic context. These researchers focus on critiquing and changing the social status quo (Orlikowski \& Baroudi, 1991).

This research project maintains an interpretive position. Neither the positivist nor the critical viewpoints can provide access to the information needed in the stated research objectives. Although previous research suggests that quantitative methods can be used, conducting statistics based analysis is unlikely to disclose the rich information that can be found in the content and context of the social interactions (Marra, 2006; Marra, Moore, \& Klimczak, 2004; Shaul, 2007) of an online community. Studying the interactions between discussion forum members, and the possible connection with fan support for a professional sport team requires qualitative methods that provide descriptive data about member interests, concerns and opinions. The interpretive viewpoint allows access to insights through social construction, which includes consciousness, language and shared meanings (Klein \& Myers, 1999; Myers, 1997). The researcher will attempt to interpret member statements and evaluate them to build an understanding of member experience and possible connections to the football team objectives.

\section{Strategy of Inquiry}

This research study draws on qualitative research methodologies, which seek to describe and classify human experience (Marshall \& Rossman, 2006; Polkinghorne, 2005). These approaches fit well within the interpretive ontology (Draper, 2004; Vivar, McQueen, Whyte \& Armayor, 2007) as they can facilitate the researcher's understanding of the cultural and social aspects of peoples' lives (Myers, 1997). Gorman and Clayton (2005) 
declare the purpose of qualitative research as describing and understanding, rather than prediction or control. Polkinghorne (2005) says that qualitative methods are specifically designed to study the experiences of people. In the absence of established theories, this research will need to focus on developing meaning from participant views. According to Draper (2004), qualitative research is "broadly characterised by the process of analytical induction, in which the researcher moves from observation to generalisation" (p. 642). Thus, a hypothesis can be constructed from observation-based inferences.

Although this research study focuses on the interactions between Yellow Fever members, the implications extend beyond the organisation to cover a wider online community. This study raises two questions. The first refers to Yellow Fever member participation in the online discussion forum, and the possible influence on fan support for the Wellington Phoenix. As previously discussed, fan support incorporates the concepts on spectator identification and sport product consumption. Thus, discussion topics related to attendance, merchandise and ticket sales are strongly relevant to this question. The second involves a search for any factors or issues that could positively or negatively affect Yellow Fever members in supporting the Wellington Phoenix.

Vivar, et al. (2007) describe five qualitative traditions, including biography, phenomenology, ethnography, grounded theory and case study. Broadly speaking, a biographical study concentrates on the experiences of an individual. Phenomenology studies the meaning of several individuals' experiences. Ethnographic research examines a social group by directly participating in the day-to-day lives of people. Case studies provide an exhaustive exploration of a single case (Creswell, 1998). 
This research employs a phenomenological approach. This decision is consistent with the study of online discussion forum member interactions. According to Kupers (2005), research can only be conducted within the context of the researcher's lived experiences. To understand the theory behind particular methodologies, it is necessary to differentiate them from other forms of qualitative study (Goulding, 2005). Phenomenology is designed to extend an understanding of complex issues through the experience, which includes thinking, feeling and doing (Goulding, 2005; Kupers, 2005).

Since many Yellow Fever members preserve their privacy by using online pseudonyms, direct observation of these participants could not be accomplished without impinging on their anonymity. As a passive member of the Yellow Fever online discussion forum, the researcher has an appreciation for how community members view Wellington Phoenix commercial and on-the-field performance.

\section{Data Collection}

When conducting qualitative research, researchers largely collect data in the form of spoken or written language (Polkinghorne, 2005). This contrasts with quantitative research, and its emphasis on numbers. This study includes data from two sources. The first set of collected data consists of archived discussion forum text. Although the information gathered from the Yellow Fever website resides in the public domain, and is freely available, the website's administrator was contacted as a courtesy to the community. The letter contained all the information necessary for full disclosure which 
included an explanation of the objectives, purpose and methods. The second set contains data collected through an online questionnaire. According to Polkinghorne, interviews or observations are more promising sources for data. An online questionnaire was selected for logistical reasons and confidentiality concerns. Moreover, research by Vasiliki \& Zafiropoulos (2006) provided an example for how an online survey could supply people's opinions and perspectives.

Prior to collecting data from the Yellow Fever website (Wellington Phoenix Discussion, n.d.), the researcher examined the online discussion forum by joining as a member. Through this initial review, the researcher formed a data collection strategy. At the time of data collection, this discussion forum contained over 72,000 posts. Considering the substantial amount of content available, the researcher opted to select only those interactions that fit timeframe and subject criteria. This strategy assures that the collected content relates to both the first season and the research questions. To find this content, the researcher searched through the online discussion forum topics using a set of keywords, including: "attend", "merchandise", "stadium", "store", "tickets", "Adelaide", "CCM", "Glory", "Melbourne", "Newcastle", and "Sydney". Search results were then assessed for topics that fit the criteria. Rather than definitively capturing every instance, the researcher strived to collect 10 to 12 good examples within each month of the first season. These examples were electronically transferred from the survey website to a local computer. The member names and dates were removed to protect privacy. 
Collecting information via an online questionnaire requires the review and approval from the School of Information Management Human Ethics Committee (Victoria University of Wellington, n.d.). The process involves adherence with university policy and guidelines. The researcher then determined that ethical approval and informed consent were necessary for this method. Committee approval was granted prior to soliciting data from forum members.

An invitation to participate in the survey was posted into the discussion forum. The post contained a complete description of the survey purpose, a disclaimer for how the information would be used, and assured that it would not collect any information that would betray participant privacy. To complete the online questionnaire, respondents selected a hyperlink which connected them to Survey Monkey (2008), a website that supplies an online questionnaire application. At the end of the agreed survey time, the researcher collected the data by electronically transferring it to a local computer (Good \& Hardin, 2006), which helps reduce any errors that could arise from transcription. Simsek and Veiga (2001) argue that online surveys provide three distinct benefits. The first benefit relates to the comparatively lower cost of administering the survey. The second is the reduced amount of time that it takes to collect the data. The third benefit involves the richness of the data. The following list supplies both the questions asked as well as an explanation for their relevance to the research topic:

\section{Question 1:}

Were you a Yellow Fever member during the 2007-08 Wellington Phoenix season? 
The purpose of this question was to determine whether the respondents were members during the 2007-08 Wellington Phoenix season. The ratio of answers can assist the researcher in determining the approximate number of return members.

Question 2:

Why did you join the Yellow Fever?

The purpose of this question was to collect member perceptions for why they joined the Yellow Fever. Allowing respondents to answer the question in their own words provides access to member experiences and perceptions.

Question 3:

What is the single best thing about the Yellow Fever website?

The purpose of this question was to draw out member motivations for continuing their membership with the Yellow Fever. This second open question provides respondents an opportunity to explain their experiences.

Question 4:

Did you attend any of the Wellington Phoenix matches?

This question is an attempt to solicit information that connects Yellow Fever membership to Wellington Phoenix attendance, which is one indicator for fan 
support.

\section{Question 5:}

Why did you become a Wellington Phoenix fan?

The purpose of this question was to collect some of the reasons for why these people became fans of the Wellington Phoenix. This third open question is intended to elicit member thinking on why they chose to follow the football club.

\section{Question 6:}

Do you intend to see the Phoenix this coming season?

Some previous research suggests that fan identification is a more direct indicator of fan support than win-loss record. This question will be compared with answers from Question 4 to see if member attendance will remain strong.

\section{Question 7:}

What is the single best thing about being a Wellington Phoenix fan?

The purpose of this question is to collect a list reasons for why these people continue to support the football club. As the fourth open question, it is intended to elicit member perspectives on why they continue to support the club. 


\section{Qualitative Data Analysis}

The primary rationale for this research study was to understand participant awareness and opinions involved with a specific phenomenon. That phenomenon is the creation and use of the Yellow Fever online discussion forum to promote fan support for the Wellington Phoenix football club. The literature review found little on the intersection between online discussion forum research and professional sporting research. Accordingly, this research study proposes to use an exploratory approach based on qualitative content analysis as described by Krippendorff (2003).

In a broad sense, the term content analysis refers to a set of procedures used as a research method for making valid inferences from narrative text (Weber, 1990; Vacc \& Loesch, 1993). The research classifies written material into smaller, more manageable chunks of information (Weber, 1990; Marra, 2006). Vacc and Loesch (1993) explain that "wordfrequency analysis" and "interpretive coding of narrative frequencies" are two well known procedures in content analysis. They each involve selecting terms and concepts that fit with a predetermined objective, and then the use of statistical processing to quantitatively understand the reliability and validity of the findings (Vacc \& Loesch, 1993). Unfortunately, this emphasis on proper statistical processing leads some researchers to overlook the transcripts. According to Marra (2006), these transcripts are probably the most useful elements. Since this research explores a relatively new area of study, it is expected that a qualitative approach, including the review and analysis of 
Yellow Fever discussion forum content, would reveal potential connections between these online forum interactions and fan support.

Using the Wellington Phoenix discussion form, the researcher searched for topics relevant to the research questions as previously described. Where the topic appeared to meet the research criteria, the researcher reviewed the list of member posts. Considering that the number of posts often exceeded fifty, the researcher summarised the member discussions into a single, descriptive paragraph. These summaries were then organised by month and accompanied by a background and monthly summary (for example, see Figure I and II).

\section{Figure I - Example Topic: "Stadium Name"}

Post 1 - "Don't you hate sponsored stadium names? It's good to have the sponsorship, or else we wouldn't have the stadiums right? But, for me, Mount Smart stadium is where New Zealand folklore has been made, no Eriksson... the Westpac Trust Stadium doesn't actually have a non-sponsored name, so herein lies the opportunity..."

Post 2 - "The Roost"

Post 3 - "The Nest"

Post 4 - "The Nest. I like - good name."

Post 36 - "The ring of fire"

Topic Summary: A moderator asks the group to come up with nicknames for the Westpac Stadium. They acknowledge that the stadium already has a sponsored name ("Westpac"), but no accepted nickname. Members reply with a variety of proposed names; some serious and some not so serious. The eventual forum favourite was posted on 10 April ("Ring of Fire").

Figure II - Example Topic: "Phoenix kit revealed" 
Post 1 - "As expected: http://au.fourfourtwo.com/news/50407,stripped-exclusivepictures-of-new-aleague-strips.aspx"

Post 2 - "I don't mind it, actually. Always been a fan of black..."

Post 3 - "Should we change our name to Black Fever?"

Post 7 - "I don't think they're all that bad. There's a bit too much black on it for my liking. I'd probably buy an away shirt if it is yellow."

Topic Summary: A member posts a link to the new Phoenix home jersey. Member replies provide opinions about the colours and style (generally positive) as well as some speculation on the shorts and away jersey. Members appear to have wanted more yellow, but accept that black reflects both the New Zealand and Wellington colours.

\section{Motivation}

King, et al. (1994) state that it is important that research promote an understanding that benefits many people's lives. This research represents an intersection between sports and Internet technology. Arguably each of these topics affects a large group of people. Promoting new understanding in this area is an opportunity to assist sport managers, website administrators and a various types of membership-based organisations achieve a better understanding for how their online communities function.

\section{Limitations and Concerns}

Three types of limits occur within this study. The first relates to the researcher's role. With the researcher representing a potential source of bias, they must exercise a certain amount of reserve (Silverman, 2004). In addition to consultation with colleagues, the researcher employed caution throughout the research. The second limit involves the use of qualitative content analysis. Some argue that qualitative research does not provide a basis 
for sound generalisations because it does not include a representative sample of the population being studied (Kelle, 2006). Others argue that the research may miss relevant categories, use theory too rigidly or discount existing diversity (Krippendorff, 2003). Since this is exploratory work, these limitations are acceptable. The third concerns the use of the Internet. Simsek and Veiga (2001) assert five concerns related to Internet research. The first is the representativeness of sample. The research must ensure that a sample represents the population from which it is drawn (Vivar, et al., 2007). The second concern relates to validity. Validity relates to assuring that a measure covers the intended phenomena (Marra, 2006). Sampling control is the third concern. Simsek and Veiga (2001) do not think that Internet research can provide sampling control which allows a researcher to generalise findings beyond the respondents. The fourth concern is that some targeted respondents do not respond to the survey (Simsek \& Veiga, 2001). This is called Nonresponse error. The fifth concern involves measurement error, which is a deviation between the true and observed responses.

In response to these concerns, and according to Vivar, et al. (2007), the goal of this qualitative research is to collect rich information rather than develop precise measures of the phenomena. Therefore, it is acknowledged that the data and findings present within this work cannot scale to situations outside the specific respondents, timeframe and phenomenon. The researcher does not intend on attributing meanings beyond what has been observed.

\section{Ethics}


Qualitative research requires human interaction which raises issues that a researcher must act to minimise (Vivar, et al., 2007). Accordingly, Vivar, et al. advise that these challenges can include conflicts of opinion and values, misunderstandings and embarrassment. Using informed consent processes and confidentiality protocols assist in dealing with ethical issues (Perlman, 2006).

Prior to collecting any research data, the researcher followed the Victoria University of Wellington human ethics policy which required the review of Human Ethics Committee (HEC) guidelines and procedures. The researcher completed a HEC application and received authorisation. When posting a link to the online questionnaire, the researcher explained the nature of the research, the voluntary nature of the survey and the confidentiality processes. Not only did these processes raise the researcher's awareness of the ethical issues, but they also improved the quality of the survey questions. 


\title{
Section 4 : Findings
}

\section{Introduction}

This section outlines the research findings according to the themes determined during the data collection and analysis phase of the study. The objective of this section is to accurately and concisely report the results as determined by the qualitative data analysis. It does not include a comparison or discussion of the findings. These will be addressed in the discussion section.

Once the posts were summarised within the relevant topics, the researcher then categorised them by month (April 2007 through January 2008). This arrangement allows a reader to either review topics as the season progresses or skip to a specific point in the season, which facilitates any connections between the topics and the other events. Moreover, the researcher added contextual information in the form of a 'background' and monthly summary (see Figure III).

Figure III - Example of Monthly Background

\begin{abstract}
April 2007
The A-League announces that the Wellington Phoenix will receive a franchise license and join the league. The Yellow Fever is formed, and they launch a website that will provide news, information and discussion forums. No player signings or matches held during this time.
\end{abstract}

\section{Findings By Month}


The A-League announces that the Wellington Phoenix will receive a franchise license and join the league. The Yellow Fever is formed, and they launch a website that will provide news, information and discussion forums. No player signings or matches held during this time.

\begin{tabular}{l|l}
\hline Topic & Summary \\
\hline Stadium Name & $\begin{array}{l}\text { A moderator asks the group to come up with nicknames for the } \\
\text { Westpac Stadium. They acknowledge that the stadium already } \\
\text { has a sponsored name ("Westpac"), but no accepted nickname. } \\
\text { Members reply with a variety of proposed names; some serious } \\
\text { and some not so serious. The eventual forum favourite was } \\
\text { posted on 10 April ("Ring of Fire"). }\end{array}$ \\
\hline Phoenix kit revealed & $\begin{array}{l}\text { A member posts a link to the new Phoenix home jersey. } \\
\text { Member replies provide opinions about the colours and style } \\
\text { (generally positive) as well as some speculation on the shorts } \\
\text { and away jersey. Members appear to have wanted more yellow, } \\
\text { but accept that black reflects both the New Zealand and } \\
\text { Wellington colours. }\end{array}$ \\
\hline $\begin{array}{l}\text { Msg to Wellington } \\
\text { from Melbourne) }\end{array}$ & $\begin{array}{l}\text { A member pledges their interest in the success of the } \\
\text { Wellington football franchise. Members discuss and generally } \\
\text { agree that (unlike other A-League teams) the Phoenix cannot } \\
\text { depend on a football tradition. So, they will need to be well } \\
\text { organised and succeed in grassroots efforts. }\end{array}$ \\
\hline $\begin{array}{l}\text { Will they spread games } \\
\text { around? }\end{array}$ & $\begin{array}{l}\text { A member reacts to the news that the Phoenix may be playing home } \\
\text { games outside of Wellington by posting his comments on Yellow } \\
\text { Fever. Most member replies generally agree and argue that team } \\
\text { support and stability cannot be achieved if the team has a moving } \\
\text { home. Whether another member argues that they could accept pre- } \\
\text { season matches away from Wellington, members tended to agree. }\end{array}$ \\
\hline
\end{tabular}

Summary: This is the first month. Members don't know what the team will look like, and are eager to find out. They are also looking forward to home matches and the availability 
of Phoenix merchandise. It was interesting to see the Melbourne fans come into the Yellow Fever forum. Some friendly jabs, but some territorial displays as well.

\section{May 2007}

Membership within the Yellow Fever begins to grow. The Wellington Phoenix has not yet played a match, and members begin to speculate about players and team performance.

\begin{tabular}{l|l}
\hline Topic & Summary \\
\hline $\begin{array}{l}\text { Pre-Season game in } \\
\text { another NZ city }\end{array}$ & $\begin{array}{l}\text { Members discuss positives and negatives of having a Phoenix } \\
\text { pre-season home game outside of Wellington. Several post } \\
\text { ideas and reasoning behind them. Christchurch and Napier two } \\
\text { favourites. }\end{array}$ \\
\hline Phoenix Store & $\begin{array}{l}\text { A moderator announces the opening date of a "Phoenix Store" } \\
\text { in Wellington. Reply comments display enthusiasm for the } \\
\text { availability of merchandise, and some disappointment about } \\
\text { unavailable jerseys. }\end{array}$ \\
\hline Free First Game? & $\begin{array}{l}\text { A member posts an idea for filling all the seats in Westpac } \\
\text { Stadium for the first game: Unsold tickets given out free. The } \\
\text { other members debate the feasibility of the idea, and generally } \\
\text { agree that it's a bad idea. The reasoning being the burden of } \\
\text { stadium costs on the team. }\end{array}$ \\
\hline $\begin{array}{l}\text { Are fans gonna travel } \\
\text { to away games? }\end{array}$ & $\begin{array}{l}\text { A member asks if anyone else will be able to attend away } \\
\text { games in Australia. Many members respond with interest. Some } \\
\text { post that they live in Auckland, Christchurch, Brisbane, Sydney } \\
\text { and Melbourne and volunteer to help organise pre- and post- } \\
\text { game functions. Other members lament costs of travel or that } \\
\text { they are too young to travel without parents. }\end{array}$ \\
\hline Scarves and Beanies & $\begin{array}{l}\text { Members discuss merchandise that is available at local stores. } \\
\text { Some lament the lack of availability. Another member suggests } \\
\text { visiting a local sport shop to buy Wellington scarves and hats. }\end{array}$ \\
\hline
\end{tabular}

Summary: Yellow Fever members continue to speculate on player acquisitions, ticket availability and merchandising. Members also debate the merits of having Phoenix 
matches outside the Wellington area. Interestingly, the members display enthusiasm when a moderator announces the opening date of the Phoenix Store.

\section{June 2007}

Membership within the Yellow Fever begins to grow. With the preseason starting in July, the Wellington Phoenix played a friendly match against a local club team.

\begin{tabular}{l}
\hline Topic \\
\hline Phoenix AWAY game \\
you would most want \\
to attend?
\end{tabular}

\begin{tabular}{l}
\hline Season Tickets \\
How Many Fans 1st \\
Home Game? \\
YF seating location at \\
the Basin Preseason \\
Game
\end{tabular}

\section{Summary}

Moderator launches a poll on which away game would members most want to attend. 25 members respond. Melbourne and Sydney each receive 7 votes. Brisbane receives 6, and Perth gets 5 and Adelaide 0 . Comments include some joking around about an Auckland reunion, and the beauty of Melbourne and Perth.

A moderator announces that Phoenix tickets are available for purchase through "Ticketek". He also notes that mentioning the phrase "Yellow Fever Zone" will place people with the rest of the Yellow Fever members. Responses are appreciative and generate more information, such as season ticket prices $(\$ 184)$. Most members happy with that price, but one member argues that they are too expensive.

A member launches a poll asking member opinions on attendance for the first home game. 81 members participate. 43 say $12,000+.23$ say between 7,000 -12,000. The rest expect less than 3,000 . There is a spirit of general optimism about the match (Actual attendance $=14,177)$.

A member posts that the Yellow Fever may have to sit behind the goal posts for a preseason match at the Wellington Basin Reserve. Members argue where they would want the Yellow Fever group to sit. They also speculate on the weather and what the ticket prices should be (Actual ticket prices $=\$ 10)$.

Tonight's Friendly Game A member asks who is attending a preseason warm-up match in Lower Hutt against a local club. The match is later that evening, and the post does not receive many replies. Those that do reply state that they were either unsure or were not attending. 


\begin{tabular}{l|l}
\hline Kit? & $\begin{array}{l}\text { A member asks about the Phoenix official jersey. Apparently, } \\
\text { it's availability to the public was delayed by the manufacturer. } \\
\text { Members don't appear to know when the jersey will be } \\
\text { available, but that doesn't stop them from speculating and } \\
\text { joking around. }\end{array}$ \\
\hline Pennants for cars??? & $\begin{array}{l}\text { A member tells a story about seeing football club pennants in } \\
\text { pubs overseas. They ask other members if the Phoenix have a } \\
\text { pennant and where they might be available. The other members } \\
\text { agree that it is a good idea, but do not have any information. }\end{array}$ \\
\hline
\end{tabular}

Summary: The members spend more time speculating about potential players; they are enthusiastic and optimistic about the Phoenix's first season. A moderator encourages discussions about attendance and tickets by adding posts and conducting polls.

July 2007

The Wellington Phoenix play preseason matches during this month.

\begin{tabular}{l|l}
\hline Topic & Summary \\
\hline Membership & $\begin{array}{l}\text { A member reports contacting the Phoenix and Ticketek for } \\
\text { membership information, but being unsuccessful. Two } \\
\text { moderators chime in. One expects media "saturation" on } \\
\text { Monday. The other offers to find more information. Other } \\
\text { members reply with speculation and information resources. The } \\
\text { topic then turns into a debate on fair ticket prices. }\end{array}$ \\
$\begin{array}{l}\text { Have you got your } \\
\text { season ticket yet? }\end{array}$ & $\begin{array}{l}\text { A member asks if other members were able to attain tickets. } \\
\text { Most replies indicate that other members were able to purchase } \\
\text { tickets without issue. However, some members do report issues } \\
\text { with the Phoenix website and with Ticketek. }\end{array}$ \\
\hline $\begin{array}{l}\text { Pre-Season Tables } \\
\text { Play-offs - how we get }\end{array}$ & $\begin{array}{l}\text { A member notes progress made by the Phoenix during the } \\
\text { preseason. Other members agree with his optimism. Yet, other } \\
\text { members caution that league scoring methods during the regular } \\
\text { season differs from preseason. }\end{array}$ \\
\hline $\begin{array}{l}\text { Live Gamecast for } \\
\text { Queensland Match }\end{array}$ & $\begin{array}{l}\text { A moderator reminds the members that an upcoming match will } \\
\text { also be accessible online via "Gamecast". Other members reply }\end{array}$ \\
\hline
\end{tabular}




\begin{tabular}{l|l}
\hline tonight & $\begin{array}{l}\text { positively, and suggest that they will view the match online as } \\
\text { well as on TV/Radio. }\end{array}$ \\
\hline Opportunity Missed & $\begin{array}{l}\text { After the Phoenix opening day, a member laments (in his } \\
\text { opinion) two missed opportunities. They were a Yellow Fever } \\
\text { recruitment booth and a merchandise shop. Other members } \\
\text { agree that opening day would have been a good place to run } \\
\text { both booths. Some speculate that the merchandise probably } \\
\text { wasn't ready anyway. }\end{array}$ \\
\hline $\begin{array}{l}\text { Who says we shouldn't } \\
\text { be organised }\end{array}$ & $\begin{array}{l}\text { Members debate the necessity of organising themselves for pre- } \\
\text { game, mid-week, etc socials. Opinion is a bit split. One member } \\
\text { invites Toronto FC supporters to join the discussion (since TFC } \\
\text { in a similar situation in MLS). }\end{array}$ \\
\hline $\begin{array}{l}\text { Supporter ages at } \\
\text { games }\end{array}$ & $\begin{array}{l}\text { Members use a poll to discuss how Phoenix should market to } \\
\text { potential fans. Survey focuses on age groups, and the discussion } \\
\text { does as well. Some interesting ideas for retaining 15-20 yr old } \\
\text { fans and attracting families. }\end{array}$ \\
\hline Phoenix vs. NPC & $\begin{array}{l}\text { Members predict home game attendance and compare numbers } \\
\text { to NPC rugby numbers. Generally, they are optimistic that } \\
\text { football will attract more people than rugby. }\end{array}$ \\
\hline
\end{tabular}

Summary: The topics selected within this month contain evidence both fan support and community behaviour. For example, when member has trouble with tickets, others offer to assist resolve the problem. In addition, members appear to be concerned with marketing opportunities, match attendances and growing the fan base. This fan support appears to go beyond buying tickets and wishing the team success.

\section{August 2007}

The Wellington Phoenix plays their first and second matches during this month. They drew their first match in Wellington. The lost their second match on the Central Coast in Australia. 


\begin{tabular}{|c|c|}
\hline Topic & Summary \\
\hline $\begin{array}{l}\text { Who's watching online } \\
\text { tonight? }\end{array}$ & $\begin{array}{l}\text { Members write to each other as they wait for the Phoenix match } \\
\text { to begin. A bit of joking around and bravado about the game. } \\
\text { Several members complain that the match should have started, } \\
\text { but that they could not get updates from Gamecast. }\end{array}$ \\
\hline $\begin{array}{l}\text { Home Friday night vs. } \\
\text { the Planes }\end{array}$ & $\begin{array}{l}\text { A moderator announces that the Phoenix will be playing on } \\
\text { Friday night in Wellington. Several members appear to be } \\
\text { concerned about publicity, crowd attendance and getting time } \\
\text { away from family duties. }\end{array}$ \\
\hline $\begin{array}{l}\text { Let's make some } \\
\text { educated picks }\end{array}$ & $\begin{array}{l}\text { A member asks the group to predict the end of season league } \\
\text { table. Most members are optimistic, and place the Phoenix in } 3^{\text {rd }} \\
\text { or } 4^{\text {th }} \text { position. Others have a laugh at the topic, and joke about } \\
\text { the Phoenix coming in last. }\end{array}$ \\
\hline $\begin{array}{l}\text { Adelaide wins Pre- } \\
\text { Season Cup }\end{array}$ & $\begin{array}{l}\text { Adelaide wins the preseason cup, and a member posts the } \\
\text { information. The topic migrates to New Zealand players who } \\
\text { play in the A-League. After several posts, it becomes apparent } \\
\text { that Adelaide has one New Zealand player, and the rest play for } \\
\text { Wellington. }\end{array}$ \\
\hline $\begin{array}{l}\text { Phoenix jerseys } \\
\text { available today!!!! }\end{array}$ & $\begin{array}{l}\text { A moderator announces that Phoenix team jerseys are available. } \\
\text { Members appear to be generally happy with this news. They } \\
\text { discuss costs, sizes and availability in Wellington as well as in } \\
\text { other cities. }\end{array}$ \\
\hline $\begin{array}{l}\text { Only complaint about } \\
\text { the crowd yesterday }\end{array}$ & $\begin{array}{l}\text { A member states that they were disappointed with the Phoenix } \\
\text { fans. Apparently, as the game went badly for the Phoenix, the } \\
\text { crowd was quiet. Members generally agree that spectators } \\
\text { should support their team regardless of whether the team is } \\
\text { headed for victory or defeat. And, support apparently equates } \\
\text { with attendance and loud vocal support. }\end{array}$ \\
\hline $\begin{array}{l}\text { Watch Friday's game } \\
\text { at the Fever Lounge }\end{array}$ & $\begin{array}{l}\text { A member organises a location for the Yellow Fever group to } \\
\text { watch an away game. The members agree that they will meet at } \\
\text { the Backbencher for home games, and organise an alternate } \\
\text { location for away games. They will call the alternative location, } \\
\text { the "Fever Lounge". }\end{array}$ \\
\hline $\begin{array}{l}\text { Yellow Fever Season } \\
\text { Launch Party - } \\
\text { Discuss }\end{array}$ & $\begin{array}{l}\text { A moderator provides information about a launch party, the } \\
\text { availability of Yellow Fever cards (to season ticket holders) and } \\
\text { free drinks. Other members thank him, and discussion covers all } \\
\text { these topics and privacy concerns (over data collected for the } \\
\text { cards). }\end{array}$ \\
\hline
\end{tabular}




\begin{tabular}{l|l}
\hline Yellow fever zone & $\begin{array}{l}\text { A member (apparently, a parent) asks if the Yellow Fever } \\
\text { section is suitable for families. The group generally suggests } \\
\text { that the Yellow Fever Zone is not an appropriate place for } \\
\text { families to sit. They cite reasons: "standing the whole game", } \\
\text { "signing songs with mature language" and "lot's of yelling". }\end{array}$ \\
\hline SEASON TICKETS & $\begin{array}{l}\text { A member posts remarks on ticket prices. A lively discussion } \\
\text { occurs with members comparing ticket prices with other } \\
\text { Australian team and the former New Zealand Kingz and } \\
\text { Knights. }\end{array}$ \\
\hline $\begin{array}{l}\text { Question from a } \\
\text { Phoenix! }\end{array}$ & $\begin{array}{l}\text { A new member asks several questions about ticket prices, how } \\
\text { many people the members think will attend and where people } \\
\text { will go for pre-match drinking. Many members provide their } \\
\text { opinion and appear genuinely helpful. }\end{array}$ \\
\hline $\begin{array}{l}\text { Will Phoenix achieve } \\
\text { its membership target? }\end{array}$ & $\begin{array}{l}\text { A moderator posts a Phoenix Chief Executive quote on } \\
\text { membership. Apparently, his goal was a target of 2,000-2,500. } \\
\text { Members debate whether those numbers are realistic. Most are } \\
\text { optimistic that those numbers are achievable. }\end{array}$ \\
\hline $\begin{array}{l}\text { Wellington Phoenix } \\
\text { Club Store }\end{array}$ & $\begin{array}{l}\text { A member hears a rumour of a Phoenix Club store on Cuba } \\
\text { Street and asks for more information. Most members don't } \\
\text { seem to know much about it, but they speculate that it is a } \\
\text { temporary thing. }\end{array}$ \\
\hline
\end{tabular}

Summary: Discussion forum activity is similar to July 2007. Members discuss players, attendance, and merchandise. They continue to display concern for Phoenix success both on and off the field.

\section{September 2007}

The Wellington Phoenix played four matches in the month of September. The results include two wins, one draw and one loss. Three of these matches occurred in Wellington.

\begin{tabular}{l|l}
\hline Topic & Summary \\
\hline Any hints towards this & A member polls the group on how many people will attend an \\
Sundays & upcoming home match. The discussion generates a lot of \\
Attendance??? & speculation on possible attendance figures. Predictions suggest \\
\hline
\end{tabular}




\begin{tabular}{|c|c|}
\hline & $\begin{array}{l}\text { a wide spectrum of possibilities (i.e. } 7,000 \text { to } 20,000 \text { ). [Actual } \\
\text { attendance }=10,800 \text { ]. }\end{array}$ \\
\hline Beckham Confirmed! & $\begin{array}{l}\text { A member announces that the Phoenix have confirmed their } \\
\text { non-league match against David Beckham (former England } \\
\text { captain and famous international player) and the Los Angeles } \\
\text { Galaxy (Major League Soccer franchise from USA). Most } \\
\text { members are clearly excited about the publicity that this will } \\
\text { generate for the Phoenix. Some are cynical, and say that } \\
\text { Beckham does not have the quality that he once had. }\end{array}$ \\
\hline Showing your colours & $\begin{array}{l}\text { A member encourages other fans to wear Phoenix gear (and/or } \\
\text { colours) to Phoenix games. Several members note that fans are } \\
\text { wearing football jerseys from English teams, which does not } \\
\text { create visible support for the Phoenix. Many support this idea, } \\
\text { but note that Phoenix gear is unavailable until October } 2007 \text {. }\end{array}$ \\
\hline $\begin{array}{l}\text { Getting Bigger } \\
\text { Crowds }\end{array}$ & $\begin{array}{l}\text { A member asks for opinions on the potential rate of attendance } \\
\text { increase. Most replies suggest optimism, but with some } \\
\text { grounded opinions suggesting that attendance figures are largely } \\
\text { affected by the home city population. They do not expect the } \\
\text { Phoenix to out perform larger cities like Melbourne and } \\
\text { Sydney. }\end{array}$ \\
\hline $\begin{array}{l}\text { Phoenix V's Australia } \\
\text { Glory (Pre-Game } \\
\text { thread) }\end{array}$ & $\begin{array}{l}\text { A member asks group to predict score for this game. Members } \\
\text { generally agree a Phoenix win (1-0). Though the discussion } \\
\text { shows varying levels of confidence and opinion. }\end{array}$ \\
\hline Supporters' gear & $\begin{array}{l}\text { Again, the members discuss the availability, costs and option } \\
\text { for purchasing supporter's gear. Some appear to be waiting for } \\
\text { the official merchandise, other opt for general Wellington } \\
\text { colours (Black and Yellow). }\end{array}$ \\
\hline $\begin{array}{l}\text { Hey does anyone know } \\
\text { where }\end{array}$ & $\begin{array}{l}\text { A member notices that some supporters had Phoenix } \\
\text { wristbands, and asks how he can obtain them. The general } \\
\text { response is that the wristbands are only available to season } \\
\text { ticket holders. }\end{array}$ \\
\hline
\end{tabular}

Summary: The Yellow Fever members continue to discuss and debate topics of fan support, including predicted attendance, availability of merchandise. Some members attempt to convince others to stop wearing their English Premier League jerseys in favour of the Phoenix black and yellow. The biggest announcement concerned an agreement for 
David Beckham and the Los Angeles Galaxy to play the Phoenix in a non-league match on 1 December.

\section{October 2007}

During this month, the Wellington Phoenix stumbled badly with four consecutive losses.

Three of these matches were in Australia and one in Wellington.

\begin{tabular}{l|l}
\hline Topic & Summary \\
\hline $\begin{array}{l}\text { Upper Hutt Phoenix } \\
\text { fans }\end{array}$ & $\begin{array}{l}\text { A member (apparently, living in Upper Hutt) attempts to } \\
\text { organise the Hutt area fans. They mention going to home games } \\
\text { together, socialising pre- and post- games and sharing parking } \\
\text { fees. Some show interest. Others take opportunity to have a } \\
\text { laugh. }\end{array}$ \\
\hline $\begin{array}{l}\text { The Adelaide game } \\
\text { thread }\end{array}$ & $\begin{array}{l}\text { A member starts the topic by commenting on this upcoming } \\
\text { match. Replies consist of game predictions, player updates, and } \\
\text { complaints about lack of defence. Some members are frustrated } \\
\text { with the coach. Others show anger about losing the match. And, } \\
\text { part of the thread turns into a plea that TV commentators stop } \\
\text { calling the Wellington Phoenix the "New Zealand" team. There } \\
\text { is even some who debate whether the Phoenix is any better than } \\
\text { the former Knights and Kingz. }\end{array}$ \\
\hline $\begin{array}{l}\text { What's with not } \\
\text { checking concession }\end{array}$ & $\begin{array}{l}\text { A member notices that the stadium staff do not ask for student } \\
\text { ID when fans purchase student tickets. Members discuss the } \\
\text { differences between adult, student and family ticket plans. } \\
\text { Some unhappy that stadium does not check people more } \\
\text { carefully. A moderator writes that he cannot understand why a } \\
\text { supporter would want to cheat their own club, and doubts it is a } \\
\text { widespread issue. }\end{array}$ \\
\hline $\begin{array}{l}\text { All Whites and Nix } \\
\text { Nov 17 }\end{array}$ & $\begin{array}{l}\text { Schedule conflict between Phoenix and New Zealand National } \\
\text { team means the coach and some players will be with the All } \\
\text { Whites instead of the Phoenix when Wellington plays Sydney. } \\
\text { The group debates the options, and general opinion sides with } \\
\text { the Phoenix. The rationale being that they have the greater need } \\
\text { for the players and coach. }\end{array}$ \\
\hline A member reports a rumour about the Stadium moving the \\
\hline
\end{tabular}




\begin{tabular}{|c|c|}
\hline tomorrow & $\begin{array}{l}\text { Yellow Fever from Aisle } 21 / 22 \text { to behind the end goals. Several } \\
\text { members speculate about the positives and negatives of such a } \\
\text { move, but generally appear against it. }\end{array}$ \\
\hline Dressing to Impress & $\begin{array}{l}\text { The members discuss Phoenix official merchandise and member } \\
\text { created t-shirts (e.g. "Petone til I die"). They also say that they } \\
\text { send Phoenix gear overseas to friends and family to help } \\
\text { "spread the word". }\end{array}$ \\
\hline $\begin{array}{l}\text { Is the Galaxy circus } \\
\text { good for the Phoenix? }\end{array}$ & $\begin{array}{l}\text { A member argues that playing the Galaxy (and David Beckham) } \\
\text { may be good for publicity and ticket revenue, but worries about } \\
\text { player fatigue. The discussion covers a diverse set of opinions } \\
\text { on these topics. }\end{array}$ \\
\hline Phoenix merchandise & $\begin{array}{l}\text { An overseas member asks about getting a Phoenix jersey in } \\
\text { Australia. Members are unsure about availability, but suggest } \\
\text { that using the online catalogue would be a safe option. }\end{array}$ \\
\hline Stadium Seating & $\begin{array}{l}\text { One member asks why the tickets are allocated when the } \\
\text { stadium is no where near selling out for Phoenix home games. } \\
\text { The group excitedly discuss the merits of allocated vs. } \\
\text { unallocated seating. Members generally agree that while the } \\
\text { seats are allocated, that it is relatively easy to move from } \\
\text { section to section and sit with friends. }\end{array}$ \\
\hline $\begin{array}{l}\text { LA Galaxy Ticket } \\
\text { Update }\end{array}$ & $\begin{array}{l}\text { A member starts a discussion about the amount of tickets sold } \\
\text { and the chances of selling out Westpac Stadium, which would } \\
\text { be the largest New Zealand crowd to ever attend a soccer } \\
\text { match. General enthusiasm through the discussion. }\end{array}$ \\
\hline $\begin{array}{l}\text { GREAT NEWS!! } \\
\text { replay of Sunday } \\
\text { Match }\end{array}$ & $\begin{array}{l}\text { A member reports that Sky TV is replaying a recent Phoenix } \\
\text { match. A moderator notes that they have a recorded copy and } \\
\text { will be screening it at an upcoming Phoenix event. }\end{array}$ \\
\hline
\end{tabular}

Summary: The Yellow Fever members continue to display fan support for the Wellington

Phoenix. They discuss attendance, merchandise and the need to wear Phoenix gear to support the team. Despite the losses, members still appear positive. Some argue patience with this first season team. Members also debate the merit of having the Galaxy, nonleague match during the season. 


\section{November 2007}

The Wellington Phoenix achieved a single win from five matches in this month.

\begin{tabular}{l|l}
\hline Topic & Summary \\
\hline Updated League Table & $\begin{array}{l}\text { A member posts an updated league table, and argues that the } \\
\text { Phoenix are not that far off from getting into playoff position. } \\
\text { The other members are optimistic about the opportunity and } \\
\text { provide opinions on which games are critical and which players } \\
\text { need to improve their performances. }\end{array}$ \\
\hline CCM vs. Victory & $\begin{array}{l}\text { A member asks about group opinion on this match. They } \\
\text { receive a mixed commentary on the match, different stadiums } \\
\text { and other football topics. }\end{array}$ \\
\hline $\begin{array}{l}\text { Yellow Fever Season } \\
\text { and T-Shirts }\end{array}$ & $\begin{array}{l}\text { A moderate asks if people have ideas for a t-shirt design for } \\
\text { season two. Members provide several ideas. Some appear to be } \\
\text { serious. Others are just having fun again. }\end{array}$ \\
\hline $\begin{array}{l}\text { Got to love our current } \\
\text { position on the ladder! }\end{array}$ & $\begin{array}{l}\text { Member frustration with the teams' position on the A-League } \\
\text { table shows within this topic. There are a lot of comments about } \\
\text { the quality of the team, and many appear to be quite sarcastic. }\end{array}$ \\
$\begin{array}{l}\text { Noenix 24th } \\
\text { November }\end{array}$ & $\begin{array}{l}\text { A member hears that the A-League is considering expansion } \\
\text { teams for next season. The group participates in a lively } \\
\text { discussion about possible new entrants, and whether the } \\
\text { Phoenix will be able to beat them and get out of last place. }\end{array}$ \\
\hline $\begin{array}{l}\text { A member attempts to organise Phoenix fans for a game in } \\
\text { Perth. A few members say they will be there, but most admit } \\
\text { factors. }\end{array}$ \\
\hline
\end{tabular}

Summary: Despite the poor results on the field, members continue to interact within the forum. These interactions include discussing matches and organising groups for away matches. The group's optimism about the team has waned. Some argue that the team still has a chance of reaching the play-offs. Others express their frustrations with strong amounts of sarcasm. 


\section{December 2007}

The Phoenix played and lost to the Los Angeles Galaxy (and David Beckham) on 1

December. The game generated the highest ever attendance for a New Zealand football match. The team played three league matches as well. With two wins and a draw, one would expect the members to be quite satisfied with the team's performance.

\begin{tabular}{l|l}
\hline Topic & Summary \\
\hline League table & $\begin{array}{l}\text { A member notes that the Phoenix could move up to sixth place } \\
\text { if the Melbourne Victory loses their next game. The group } \\
\text { happily cheers for a Melbourne loss. }\end{array}$ \\
\hline $\begin{array}{l}\text { Who Would Of } \\
\text { Thought It }\end{array}$ & $\begin{array}{l}\text { The members discuss their general satisfaction with how well } \\
\text { the first season has gone. Despite the on-field performance, they } \\
\text { see that the team is in a good situation for prospering in the next } \\
\text { season. }\end{array}$ \\
\hline $\begin{array}{l}\text { Phoenix v planes } \\
\text { match thread }\end{array}$ & $\begin{array}{l}\text { This topic consists of a number of comments that occur just } \\
\text { prior and during a Phoenix match. Many appear to be listening } \\
\text { via radio. }\end{array}$ \\
\hline $\begin{array}{l}\text { Phoenix membership } \\
\text { tickets? }\end{array}$ & $\begin{array}{l}\text { Member complains about late tickets, ticketek service, value of } \\
\text { money on tickets, and Phoenix lounge. Other members join in. } \\
\text { Some complaining about other issues, others doing some } \\
\text { problem solving. }\end{array}$ \\
\hline $\begin{array}{l}\text { A -League - players off } \\
\text { contract }\end{array}$ & $\begin{array}{l}\text { A member posts list of all A-League players who will be off } \\
\text { contract at end of season. The rest of the members debate which } \\
\text { players would be good for the Phoenix, likelihood of actually } \\
\text { acquiring them and which players should go. }\end{array}$ \\
\hline $\begin{array}{l}\text { Input needed from YF } \\
\text { Arowd tonight }\end{array}$ & $\begin{array}{l}\text { A member finds a post in Melbourne Victory forum stating that } \\
\text { New Zealand should not have teams in the A-League. Yellow } \\
\text { Fever members debate the merits of that statement and } \\
\text { wholeheartedly disagree with it. } \\
\text { home match. Several members provide information about } \\
\text { Ticketek locations, booking fees, good seats, etc. }\end{array}$ \\
\hline Members speculate on match attendance. Most expect about \\
\hline
\end{tabular}


Summary: Members debate the Phoenix's first season. Some are satisfied and patient with the team; others are frustrated or looking to player changes in the next season. Members also speculate on home attendance. Actual attendance falls short of member expectations.

\section{January 2008}

The last month of the first season was unkind to the Wellington Phoenix. They lost all three matches by a combined score of 8 to 0 .

\begin{tabular}{|c|c|}
\hline Topic & Summary \\
\hline $\begin{array}{l}\text { Grand Final } \\
\text { Relocation - possible } \\
\text { future implications }\end{array}$ & $\begin{array}{l}\text { A member posits what would happen if the Wellington Phoenix } \\
\text { hosted the A-League Grand Final. Apparently, the A-League } \\
\text { has a rule that states that the host stadium must hold at least } \\
40,000+\text { seats or risk losing the final to another venue. Members } \\
\text { agreed that the } 34,500 \text { seat Westpac Stadium could be expanded } \\
\text { to } 38,000 \text { with temporary seating, but that is all. Some members } \\
\text { have a laugh at the unlikely event occurring. }\end{array}$ \\
\hline Goal Of The Season & $\begin{array}{l}\text { A member runs a poll on the best Phoenix goal of the year. The } \\
\text { members discuss the poll as well as the goals that they thought } \\
\text { were the best. }\end{array}$ \\
\hline $\begin{array}{l}\text { Final weekend league } \\
\text { table }\end{array}$ & $\begin{array}{l}\text { A member posts the latest A-League table, and members } \\
\text { discuss the current position of the Phoenix. Generally they are } \\
\text { not happy with how things have turned out, but still manage to } \\
\text { discuss the formula used by the league. }\end{array}$ \\
\hline Second Best Team & $\begin{array}{l}\text { The members accept that the Phoenix will not get into the } \\
\text { playoffs, so they speculate who will win the competition to } \\
\text { become the "second best team". People are still joking around a } \\
\text { bit despite the season results. }\end{array}$ \\
\hline Melbourne game & $\begin{array}{l}\text { Some members appear to be quite excited about the upcoming } \\
\text { game in Melbourne. Several assert that they will be attending } \\
\text { the match. }\end{array}$ \\
\hline $\begin{array}{l}\text { 1st season crowd } \\
\text { average }\end{array}$ & $\begin{array}{l}\text { A member posts the average attendance for home games in the } \\
\text { first season (i.e. } 11,000+\text { ), and the group celebrates the }\end{array}$ \\
\hline
\end{tabular}


achievement.

Summary: A somewhat sombre finish to the season. The members partake in debates on the best Phoenix goal and which team will win the competition. The only thing that the members manage to celebrate was the average home game attendance of $11,000+$.

\section{Online Questionnaire}

The online questionnaire consisted of seven questions. Four of these questions elicited open responses.

1. Were you a Yellow Fever member during the 2007-8 Wellington Phoenix season?

\begin{tabular}{l|c}
\hline Answers & Response Count \\
\hline Yes & 65 \\
\hline No & 9 \\
\hline
\end{tabular}

Summary: Most respondents report that they were Yellow Fever members during the 2007-08 A-League season.

2. Why did you join the Yellow Fever?

\begin{tabular}{l|c}
\hline Answer Types & Frequency \\
\hline Support the Phoenix & 32 \\
\hline Passion about football & 18 \\
\hline Get information about Phoenix & 18 \\
\hline To discuss football & 9 \\
\hline Camaraderie & 6 \\
\hline To support Wellington & 6 \\
\hline Attending games is more fun & 4 \\
\hline Reasonable ticket prices & 2 \\
\hline
\end{tabular}

$\underline{\text { Examples }}$

- "Enjoyed the atmosphere at the games,very exciting being in an animated crowd in Wellington! The quality of the play, the very reasonable season ticket price too." 
- "For the enjoyment of being able to watch professional football as part of a fan base and also to engage in online discussions from time to time as a way of obtaining information and exchanging views."

- "It seemed to be the natural progression from being a Nix fan to become part of the supporters club and become totally emersed in the experience."

- "The opportunity to be in a fan club of a local football team, after so many years of deprivation, was just too good to be passed up"

- "I joined Yellow Fever originally when i first heard that the site had been created right back in the early days. I wanted to show my support for a New Zealand franchise in the A-league"

- "Because of the great atmosphere they bring to the matches, even on TV. There's nothing like it in New Zealand. I live in Christchurch however have decided I'm going to travel for every match."

- "We were excited about Wellington having a professional football team, checked out the Yellow Fever site, then decided to join as there seemed to be heaps of dedicated, like-minded people involved. As well as it being a very professional website"

3. What is the single best thing about the Yellow Fever website?

\begin{tabular}{l|c}
\hline Answer Types & Frequency \\
\hline Opportunity to exchange views & 36 \\
\hline Get timely football news & 27 \\
\hline Feel a part of a community & 7 \\
\hline
\end{tabular}

$\underline{\text { Examples }}$

- "Many things but up to minute football news a biggie, then being able to discuss or see points of view relating to the news being discussed in the forums."

- "The website is a good source of timely information. Often developments in the ALeague appear on the website earlier than official media releases."

- "It brings together everything I need as a Nix supporter, up to the minute news (links to the club so news announcements get to us quick plus links to stories from 
other sources as well), entertaining forums and event news all in the one place. Great bunch of guys too (oops, that's 2 sorry)."

- "The number of people who are passionate about NZ football and I could express other football development ideas for the future. I was not getting the some local $N Z$ football feedback anywhere else on other football forums on the net because they are oversea forums."

- "The information you gain. Wouldn't know half the stuff about the phoenix if wasn't for the site."

- "It's so up to date. Space to talk about all things football in the forum ie player's form, all whites etc."

- "Sense of unified community from various backgrounds, age groups and other various demographics."

4. Did you attend any of the Wellington Phoenix matches?

\begin{tabular}{l|c}
\hline Answers & Response Count \\
\hline Yes & 67 \\
\hline No & 7 \\
\hline
\end{tabular}

Summary: Most respondents report that they have attended matches during the first season.

5. Why did you become a Wellington Phoenix fan?

\begin{tabular}{l|c}
\hline Answer Types & Frequency \\
\hline Passionate about the sport & 43 \\
\hline Because they are in Wellington & 26 \\
\hline Only New Zealand football team & 7 \\
\hline Good social activity & 5 \\
\hline They aren't the Kingz or Knights & 2 \\
\hline Sick of rugby & 2 \\
\hline
\end{tabular}

Summary

- "I'm a serious football fan and the Wellington Phoenix have enabled me to watch live a professional football team that plays in my home city in a competition that is reasonably entertaining and enjoyable." 
- "I'm a proud born and bred Wellingtonian so would support them regardless. But after the Melbourne Victory game last season I was totally hooked."

- "As a football fan, football essentially being a minority sport in this country, I felt and still feel that it is important to support football in this city, be that attending Phoenix games or other football in this city."

- "I have done and will always support anything to do with soccer in NZ. Plus they are in my home town and the opportunity to watch live football of that level had never presented itself before. Plus I am proud to be a wellingtonian"

- "Been a football fan as long as I can remember and have been to a handful of professional games in different countries around the world. The football "experience" and atmosphere is second-to-none so when a pro club was formed in my home town there was no question that I would be a fan"

6. Do you intend to see the Phoenix this coming season?

\begin{tabular}{l|c}
\hline Answers & $\begin{array}{c}\text { Response } \\
\text { Count }\end{array}$ \\
\hline Yes & 68 \\
\hline No & 6 \\
\hline
\end{tabular}

Summary: Most respondents report an intention to attend Phoenix matches in the 2008-09 season.

7. What is the single best thing about being a Wellington Phoenix fan?

\begin{tabular}{l|c}
\hline Answer Types & Frequency \\
\hline The atmosphere at the games & 19 \\
\hline A sense of community / camaraderie & 14 \\
\hline Only professional football team & 13 \\
\hline Good quality football & 4 \\
\hline Yellow Fever & 4 \\
\hline Winning & 3 \\
\hline Coach & 1 \\
\hline
\end{tabular}

Summary 
- "Having something to look forward to every weekend and knowing that for 2 hours a week you can just forget about everything else."

- "Having a local footy club to support, watching all the rugby-heads drop scathing comments because they're jealous."

- "Bonding together with like minded people, its fun, the games are lively and entertaining and the atmosphere is brilliant, best sports atmosphere in NZ sport."

- "A feeling of actually belonging to a team that means something to me, Leeds United are great, but having never lived in Leeds they seem too distant to get too involved in."

- "Everyone's right in behind them, they're competitive, there are many kiwis in the team, good coach, exciting to watch (good style)" 


\section{Section 5: Discussion}

The focus of this section is to discuss the findings stated in the previous section. The primary rationale for this research is to understand Yellow Fever members use their online discussion forum to generate support for the Wellington Phoenix. This work was brought about by a perceived gap in the research literature, which does not appear to address potential relationships between Internet technologies and support for professional sport organisations.

The research was conducted using two data collection methods to understand Yellow Fever member actions, awareness and perspectives. The first involved an analysis of archived discussion forum posts. The second comprised of an open invitation to Yellow Fever members to participate in an online questionnaire. Each method yielded data that relates to the stated research questions.

\section{Research Question 1}

Does participation in the Yellow Fever online discussion forum influence fan support for the Wellington Phoenix Football Club?

The first research question simply asks for evidence that Yellow Fever discussion forum activity influences fan support. The literature review revealed three distinct perspectives on fan support, all of which are evident in these research findings. Where fan support could equate to spectator consumption of sporting events or extension products (Murrell \& Dietz, 1992), the discussion forum provides a number of examples where members inquire about match tickets and merchandise. On each occasion, other members appear 
eager to assist others attain these items. For example, when a moderator announces the unveiling of the Wellington Phoenix team uniforms April 2007, the members seem enthusiastic as they debate the colours and style chosen. When the team jerseys become available in August 2007, the members send posts declaring their excitement of the prospect of attaining team merchandise.

A second perspective on fan support involves spectator loyalty and emotional connection to a sport figure or group (Smith \& Wheeler, 2002). As with the previous viewpoint of fan support, the research finds examples of Yellow Fever member online interaction from the inception of the Wellington Phoenix discussion forum. When a member pledges that they will support the Phoenix regardless of the match results, other members join into a discussion of tactics without questioning whether it is their responsibility or not. They appear to agree that this football team cannot succeed without their organising a grassroots effort to increase fan support. A month later, a member posts an idea that would most likely guarantee a full stadium for the Phoenix's first home match. On the surface, the member's suggestion that the team buy up the unsold tickets and distribute them for free appears to be reasonable idea for generating more fans. However, posts from other Yellow Fever members argue that the financial burden on the Wellington Phoenix did not merit the effort. These reactions denote an apparent regard for the financial health and well-being of the football club that exceeds mere entertainment or eustress. Another example of emotional connections between Yellow Fever members and support for the Wellington Phoenix occurs in August 2007. A member observes that many spectators in his section of the stadium had become quiet when the Phoenix had fallen behind in the 
match. His post expresses his disappointment that people did not support the team regardless of the situation. Several other members add their agreement and support his argument that spectators have a responsibility to support their team regardless of how they perform. This sense of responsibility aligns with fan support defined as spectator loyalty. Lastly, when asked via the online survey for the reasons that members joined the Yellow Fever, most respondents stated that they wished to support the team, the sport, the city or experience camaraderie with fellow football fans.

The third perspective on fan support relates to how spectators identify with a sport individual or group; the strength of which influences consumption behaviours (Fisher \& Wakefield, 1998). This type of fan support is the most difficult to examine. Although the online forum contains examples of members who identify strongly with the sporting franchise and purchase tickets and merchandise, the relationship cannot be further explained at this time. The direction or existence of a cause-and-effect relationship is not apparent. For example, members were greatly concerned about that the Westpac Stadium did not have a nickname. Although, it was only April, this topic spanned several days, until members started to rally around a particular suggestion. Some members did not appear to take the topic very seriously, but those that did continued to post suggestions until members started to informally vote on the eventual winner. Another example of spectators who identify with the team includes the member who posted the "Missed Opportunity" topic in July 2007. Reading the initial post, one could mistakenly believe that the member was a salaried employee or marketing consultant. The topic begins with his lamenting two missed opportunities. The first was that the Yellow Fever did not 
organise a recruitment booth. A sceptic could argue that this support was directed toward the Yellow Fever rather than the Wellington Phoenix. However, the second missed opportunity involves a Wellington Phoenix merchandise booth. Though it is possible that the member was just thinking entrepreneurially, one cannot dismiss the reactions of the many other members who endorsed both ideas because they observed a potential benefit for the football team. A third example of fan support occurs in October 2008. A member notices that spectators can buy student rate tickets without presenting student identification. Several members appear to be irate that stadium staff are not looking after their team's interest. Still, the most poignant comment belonged to a moderator who simply stated that he could not understand why anyone would want to cheat their own club. It is that sense of ownership and inclusion that denotes identification with not only the online community, but also with the club itself.

The first research question simply asks for evidence that Yellow Fever discussion forum activity influences fan support. Therefore, the first question can be answered in the affirmative. Participation in the Yellow Fever online discussion forum does appear to generate fan support for the Wellington Phoenix football club.

\section{Research Question 2}

In what ways do the Yellow Fever members impact fan support for the Wellington Phoenix?

The second research question explores the conditions that could promote fan support for the Wellington Phoenix. To examine the possible conditions, the literature provides four 
areas where Yellow Fever members can demonstrate fan support behaviours. The first way that members can demonstrate support by attending Wellington Phoenix matches which includes participating as a spectator, purchasing food and related items (Murrell \& Dietz, 1992). Though the discussion forum data cannot link member intentions to actual attendance, the Yellow Fever members declare their eagerness to attend matches as well as pre- and post-match functions throughout the 2007-08. When members conduct attendance polls in June, July and September, several members affirm their intent to attend and loudly support the Phoenix. Members even debate the potential rate of attendance growth within the "Getting Bigger Crowds" topic of September 2007. Some members appear to have put ample energy and thought into their posts, which posit that stadium attendance will always be constrained by a city's population. When responding to the online questionnaire, nearly all of the respondents declare that they had attended Wellington Phoenix matches in 2007-08 and would attend in the second season. This data suggests that Yellow Fever members do support the Wellington Phoenix by way of attendance.

According to Frey and Eitzen (1991), fan support can involve access to sporting events. Since they do not distinguish between direct event attendance and indirect forms of access, it is assumed that this method of fan support can include television, radio and Internet. The Yellow Fever members mention television, radio and Internet in their posts. In July 2007, a moderator announces to the members that the Yellow Fever website will transmit a "live GameCast" of a Wellington Phoenix match. This supplies members with real-time information on the match. Member posts suggest that many will access the 
match via this website in addition to watching it on television. In August, the members watch another away match while interacting online. For another away match, the members organise a "Fever Lounge" to watch a match together at a local pub. This suggests that Yellow Fever members also support the team via television, radio and online access.

A third way that Yellow Fever members can display fan support is to advocate on behalf of the team (Smith \& Wheeler, 2002). Several examples of these types of behaviours continue throughout the 2007-2008 A-League season. For example, in the topic "Message to Wellington" in April 2007, members agree that the Wellington Phoenix do not have a traditional following of fans to rely on and they pledge to organise a grassroots effort to grow support for the team. In May, members discuss the availability of merchandise and help one another attain items from local shops. Later in the season, a new member posts a topic that asks the Yellow Fever for assistance with tickets and pre-match function information. Several members take action to assist the new member and assure that they can join the activities. Lastly, the members declare an overall satisfaction for how well the first season resulted in terms of attendance. This is despite the poor win-loss record. The Yellow Fever members consistently represent a sense of community, inclusion and fun. Their efforts suggest that they do advocate on behalf of the Wellington Phoenix.

The fourth way that Yellow Fever members can display support for the Wellington Phoenix is through camaraderie, or adding to a sense of community amongst the spectators. Although the online discussion forum contains numerous examples of 
collaboration, emotion and support, the topic of camaraderie does not surface until the members answer some of the open questions in the survey questionnaire. For example, responses to Question 2 - Why did you join the Yellow Fever? - include several references to camaraderie. When asked their perspectives on the "single best thing" about the Yellow Fever website, several responses appear to relate to attaining a sense of camaraderie and community. The last example relates to Question 7, which asks Yellow Fever members about "the single best" benefit of becoming a Wellington Phoenix fan. Most of the responses stated that the game atmosphere and sense of community/camaraderie were the most important benefit. This suggests that Yellow Fever members do exhibit fan support via camaraderie and community.

The second research question asks for example of how Yellow Fever discussion forum activity influences fan support. This study finds that the Yellow Fever members support the Wellington Phoenix in several ways, including attending matches, purchasing merchandise, accessing other matches via media channels, advocating on behalf of the team, assisting others with issues and experiencing a common sense of community. 


\section{Section 6- Conclusion}

The parallel growth in Internet usage and professional sports consumption represent two significant trends in modern society. Despite an extensive search across sport and technology literatures, the researcher was unable to find enough of a research basis to form theories which could be tested through further research. Thus, this paper explores this relatively overlooked research gap. The approach to this exploration centred on how the Yellow Fever online discussion group activities and perspectives could influence overall fan support for the Wellington Phoenix football club. The research methodology included collecting archived online posts and inviting Yellow Fever members to complete an online questionnaire.

The findings confirm that Yellow Fever members influence general fan support for the Wellington Phoenix. The members posted messages consistent encouraging attendance and merchandise sales. They display an emotional connection and loyalty to the team throughout the first season. When asked for their perceptions about the community, team and website, it appears that many members have a strong affinity with the Yellow Fever and Wellington Phoenix. In essence, the Yellow Fever is a subgroup of Wellington Phoenix fans. They distinguish themselves through a strong commitment to assisting a newly formed team.

The findings also produce some likely methods in which fan support occurs. Fan support was exhibited as member attendance and merchandise buying, match access via media channels, assisting other members, advocating on behalf of the team and co-creating a 
sense of camaraderie and community. Despite some limitations, there are implications for sporting clubs and technology organisations. For example, if online discussion forum activity influences support, sporting organisations can encourage a subset of core fans to influence fan support across a wider group of fans. This would give these organisations additional options for boasting attendance and stadium atmosphere. Another example relates to technology research which often aims to show how technology can enable business improvement and people's lives. If online community members can influence real-world behaviours, then researchers can use the related factors to study other wider social situations. The study also provides a basis for further research both with sport support groups as well as other types of membership dependent organisations such as community projects, local schools and political organisations. 


\section{Section 7- References}

Avid supporters still produce a great song and dance. (2006, August 27). New Zealand Herald. Retrieved June 22, 2008, from http://www.nzherald.co.nz/section/4/story.cfm?c_id=4\&objectid=10398219

Beech, J., Chadwick, S., \& Tapp, A. (2000). Emerging trends in the use of the Internet lessons from the football sector. Qualitative Market Research, 3, 1, 38-46.

Beuchot, A., \& Bullen, M. (2005). Interaction and interpersonality in online discussion forums. Distance Education, 26, 1, 67-87.

Bickart, B. \& Schindler, R. M. (2001). Internet forums as influential sources of consumer information, Journal of Interactive Marketing, 15, 3, 31-40.

Bloc 5. (n.d.). Retrieved March 4, 2008, from http://www.bloc5.com

Campbell, J. (1997). The impact of videoconferenced meetings on the pattern and structure of organisational communication. Singapore Management Review, 19, 1, 77-95.

Cao, J., \& Everard, A. (2008). User attitude towards instant messaging: the effect of espoused national culture. Journal of Global Information Technology Management, 11, 2, 30-58.

Chisholm, M. (2007). Wiki, waki, woozi. DM Review, 17, 11, 32-35.

Coates, D., \& Humphreys, B. R. (2007). Ticket prices, concessions and attendance at professional sporting events. International Journal of Sport Finance, 2, 161-170.

Cothrel, J. P. (2000). Measuring the success of an online community. Strategy \& Leadership, 28, 2, 17-23.

Creswell, J. W. (1998). Qualitative Inquiry and Research Design: Choosing Among Five Traditions. Sage Publishing. Thousand Oaks.

Creswell, J. W. (2003). Research Design: Qualitative, Quantitative, and Mixed Method Approaches. Sage Publishing. Thousand Oaks. 
Cunningham, J. W., \& Fitzgerald, J. (1996). Epistemology and Reading. Reading Research Quarterly, 31, 1, 36-60.

Dale, B., van Iwaarden, J., van der Wiele, T., \& Williams, R. (2005). Service improvement in a sports environment: a study of spectator attendance. Managing Service Quality, 15, 6, 470-484. Retrieved May 29, 2007, from Emerald Group Publishing Limited.

Dern, D. P. (1994). The Internet Guide for New Users. Computing McGraw-Hill (570 pp). London.

Dixon, G. (2007). A Knight's tale. Metro, 308, 72-73.

Draper, A. K. (2004). The principles and application of qualitative research. Proceedings of the Nutrition Society, 63, 641-646.

Espitin-Escuer, M., \& Garcia-Cebrian, L. I. (2006). Performance in sports teams: Results and potential in the professional soccer league in Spain. Management Decision, 44, 8, 1020-1030.

Farquhar, J., \& Rowley, J. (2006). Relationships and online consumer communities. Business Process Management Journal, 12, 2, 162-177.

Fisher, R. J., \& Wakefield, K. (1998). Factors leading to group identification: a field study of winners and losers. Psychology and Marketing, 15, 1, 23-40.

Flor, N. V. (2006). Addressing the problem of content restrictions in online community forums. Journal of Information Technology Case and Application Research, 8, 1, 7-33.

Foster, C. (2006). Failed invasion - New Zealand sport's dismal record in Australian competitions. Investigate, 6, 71, 68-69.

Frey, J. H., \& Eitzen, D. S. (1991). Sport and society. Annual Review of Sociology, 17, 503-522.

Fullerton, S., \& Merz, G. R. (2008). The four domains of sports marketing: a conceptual framework. Sport Marketing Quarterly, 17, 2, 90-109. 
Good, P. I., \& Hardin, J. W. (2006). Common Errors in Statistics (And How to Avoid Them). John Wiley \& Sons. New Jersey.

Gorman, G. E., \& Clayton, P. (2005). Qualitative Research for the Information Professional. Facet Publishing. London.

Goulding, C. (2005). Grounded theory, ethnography and phenomenology: A comparative analysis of three qualitative strategies for marketing research. European Journal of Marketing, 39, 3/4, 294-309.

Greenwell, T. C., Fink, J. S., \& Pastore, D. L. (2002). Perceptions of the Service Experience: Using Demographic and Psychographic Variables to Identify Customer Segments. Sport Marketing Quarterly, 11, 4, 233-241.

Guba, E. S., \& Lincoln, Y. S. (1994). Handbook of Qualitative Research. Sage Publications. Thousand Oaks.

Hart, C. (1998) Doing a Literature Review: Releasing the Social Science Research Imagination. Sage Publications. London.

Hoyle, R. (2005). Professional sport in Australia and New Zealand: An introduction to the special issue. Sport Management Review, 8, 89-93.

Kelle, U. (2006). Combining qualitative and quantitative methods in research practice: purposes and advantages. Qualitative Research in Psychology, 3, 293-311.

Kennedy, G. (1995, August 11). No flash cars, no fat salaries, just the hard grind of saving soccer. The National Business Review, 27.

King, G., Keohane, R. O., \& Verba, S. (1994). Designing Social Inquiry: Scientific Inference in Qualitative Research. Princeton University Press. New Jersey.

Klein, H. K., \& Myers, M. D. (1999). A set of principles for conducting and evaluating interpretive field studies in information systems. MIS Quarterly, 23, 1, 67-89.

Knights have licence revoked by soccer body. (2006, December 14). New Zealand Herald. Retrieved March 22, 2008, from http://www.nzherald.co.nz/section/4/story.cfm?c_id=4\&objectid=10415468 
Know your fever. (n.d.). Retrieved March 4, 2008, from http://www.yellowfever.co.nz/about.asp

Krippendorff, K. (2003). Content Analysis: An Introduction to Its Methodology. Sage Publications. London.

Kupers, W. (2005). Phenomenology of embodied implicit and narrative knowledge. Journal of Knowledge Management, 9, 6, 114-134.

Madrigal, R. (2006). Measuring the multidimensional nature of sporting event performance consumption. Journal of Leisure Research, 38, 3, 267-292.

Marra, R. M. (2006). A review of research methods for assessing content of computermediated discussion forums. Journal of Interactive Learning Research, 17, 3, 243267.

Marra, R. M., Moore, J. L., \& Klimczak, A. K. (2004). Content analysis of online discussion forums: A comparative analysis of protocols, Educational Technology, Research and Development, 52, 2, 23-40.

Marshall, C., \& Rossman, G. B. (2006). Designing Qualitative Research. Sage Publications. London.

Mason, D. S. (1999). What is the sports product and who buys it? The marketing of professional sports leagues. European Journal of Marketing, 33, 3/4, 402-418.

McKewen, T. (2008, January 30). Game on as new sports win the battle for fans. The Independent Financial Review, 15.

Millen, D. R., \& Dray, S. M. (2000). Information sharing in an online community of journalists. Aslib Proceedings, 52, 5, 166-173.

Miller, T., Lawrence, G., McKay, J., \& Rowe, D. (2001). Globalization and Sport. Sage Publications. London.

Moore, J. L., \& Marra, R. M. (2005). A comparative analysis of online discussion participation protocols. Journal of Research on Technology in Education, 38, 2 , 191-212. 
Morville, P., Rosenfeld, L., Janes, J., \& DeCandido, G. A. (1999). The Internet Searcher's Handbook: Locating Information, People and Software. Neal-Schuman Publishers. New York.

Murrell, A. J., \& Dietz, B. (1992). Fan support of sport teams: the effect of a common group identity. Journal of Sport and Exercise Psychology, 14, 1, 28-39.

Myers, M. D. (1997). Qualitative research in information systems. MIS Quarterly, 21, 2, 241-242.

Nicolopoulou, K., Kostomaj, M., \& Campos, A. (2006). How to address group dynamics in virtual worlds, Springer-Verlag London Limited, 20, 351-371.

Nonnecke, B., Andrews, D., \& Preece, J. (2006). Non-public and public online community participation: Needs, attitudes and behavior. Electronic Commerce Research, 6, 7-20.

Orlikowski, W. J., \& Baroudi, J. J. (1991). Studying information technology in organizations: Research approaches and assumptions. Information Systems Research, 2, 1-28.

Pappas, M. L. (2002). Discussion forums: A tool for collaboration. Knowledge Quest, 31, 2, 17-20.

Parameswaran, M., \& Whinston, A. B. (2007). Research issues in social computing. Journal of the Association for Information Systems, 8, 6, 1, 336-350.

Parr, J., \& Ward, L. (2006). Building on foundations: Creating an online community. Journal of Technology and Teacher Education, 14, 4, 775-793.

Patterson, C. (2008, January 7). Man who made the Phoenix fly, The Dominion Postdompost.co.nz. Retrieved February 15, 2008, from http://www.stuff.co.nz/4346052a6482.html

Perlman, D. (2006). Putting the "ethics" back into research ethics: a process for ethical reflection for human research protection. Journal of Research Administration, 37, $1 / 2,13-24$. 
Polkinghorne, D. E. (2005). Language and meaning: data collection in qualitative research. Journal of Counseling Psychology, 52, 2, 137-145.

Pons, F., Mourali, M., \& Nyeck, S. (2006). Consumer orientation toward sporting events. Journal of Service Research, 8, 3, 276-287. Retrieved May 30, 2007, from Emerald Group Publishing Limited.

Popular Culture. (n.d.). Retrieved March 17, 2008, from http://www.teara.govt.nz/NewZealanders/NewZealandPeoples/English/12/en

Primeaux, R. O., \& Flint, D. (2004). Instant messaging: does it belong in the workplace? Intellectual Property \& Technology Law Journal, 16, 11, 5-8.

Raman, M. (2006). Wiki technology as a "free" collaborative tool within an organizational setting. Information Systems Management, 23, 4, 59-64.

Rosenberg, R. S. (2004). The Social Impact of Computers, $3^{\text {rd }}$ Edition. Elsevier Academic Press. San Diego.

Scherer, J., Falcous, M., \& Jackson, S. (2008). The Media Sports Cultural Complex Local-Global Disjuncture in New Zealand/Aotearoa. Journal of Sport and Social Issues, 32, 1, 48-71.

Shank, M. D. (1999). Sports Marketing: A Strategic Perspective. Prentice Hall. New Jersey.

Shaul, M. (2007). Assessing online discussion forum participation. International Journal of Information and Communication Technology Education, 3, 3, 39-47.

Shilbury, D., Quick, S., \& Westerbeek, H. (2003). Strategic Sport Marketing. Allen \& Unwin. Sydney.

Silverman, D. (2004). Qualitative Research: Theory, Method and Practice. Sage Publications. London.

Simsek, Z., \& Veiga, J. F. (2001). A primer on Internet organisational surveys.

Organizational Research Methods, 4, 3, 218-236. 
Smith, S., \& Wheeler, J. (2002). Managing the customer experience: Turning customers into advocates. Prentice Hall.

Snipes, R. L., \& Ingram, R. (2007). Motivators of collegiate sport attendance: a comparison across demographic groups. Innovative Marketing, 3, 2, 61-74.

Stewart, B. (2007). The Games are Not the Same: The Political Economy of Football in Australia. Melbourne University Publishing. Melbourne.

Stop press. (2007, December). Marketing Magazine, 1-4.

Survey Monkey. (2008). Retrieved April 28, 2008, from http://www.surveymonkey.com/s.aspx?sm=ORt9_2bvjqLYKTZGCuVrc8NA_3d_3 $\underline{\mathrm{d}}$

Theodorakis, N., Kambitsis, C., Laios, A., \& Koustelios, A. (2001). Relationship between measure of service quality and satisfaction of spectators in professional sports. Managing Service Quality, 11, 6, 431-438. Retrieved May 29, 2007, from ProQuest database.

Thwaites, D. (1999). Closing the gaps: service quality in sport tourism. Journal of Services Marketing, 13, 6, 500-516.

Vacc, N. A., \& Loesch, L. C. (1993). A content analysis of opinions about the national counsellor examination. Journal of Counseling and Development, 71, 4, 418-422.

Vasiliki, V., \& Zafiropoulos, C. (2006). Tourism agents' attitudes on internet adoption: an analysis from Greece. International Journal of Contemporary Hospitality Management, 18, 7, 601-608.

Victoria University of Wellington. (n.d.). Retrieved March 3, 2008, from http://www.sim.vuw.ac.nz/research/hec/index.aspx

Vivar, C. G., McQueen, A., Whyte, D. A., \& Armayor, N. C. (2007). Getting started with qualitative research: developing a research proposal. Nurse Researcher, 14, 3, 60-74.

Weber, R. P. (1990). Basic Content Analysis. Sage Publications. London. 
Wellington Phoenix Discussion. (n.d.). Retrieved March 4, 2008, from

http://www.yellowfever.co.nz/forum/forum_topics.asp?FID=1

Wellington Phoenix. (n.d.). Retrieved March 3, 2008, from

http://www.wellingtonphoenix.com/default.aspx?s=wellfc_fixtureresults\&seasoni $\underline{\mathrm{d}=97}$

Westerbeek, H., Smith, A., Turner, P., Emery, P., Green, C., \& van Leeuwen, L. (2005).

Managing Sport Facilities and Major Events. Sydney: Allen \& Unwin.

What's been on at the Stadium. (n.d.). Retrieved March 3, 2008, from

http://www.westpacstadium.co.nz/information/facts/what.cfm

Wilson, S. M., \& Peterson, L. C. (2002). The anthropology of online communities.

Annual Review of Anthropology, 31, 449-467. 


\section{Appendix}

The following represents a complete and uncategorised list of open-question responses to the online questionnaire.

\section{Why did you join the Yellow Fever?}

» "enjoyed the atmosphere at the games,very exciting being in an animated crowd in Wellington! the quality of the play, the very reasonable season ticket price too."

» "to support the Phoenix"

» "To support the team the best I can whilst living outside of Wellington"

" "Passionate about football and Wellington"

» "keep up to date with any phoenix happening"

» "For the enjoyment of being able to watch professional football as part of a fan base and also to engage in online discussions from time to time as a way of obtaining information and exchanging views."

» "information on the team, plus to join my fellow supporters in discussing the developments."

» "Life football player and fan from Wellington. Best way to support out only professional football outfit. Als has close ties to other regional football activities."

» "Got me reduced prices at various franchaises."

» "Get information about the Phoenix"

» "To keep up to date with any news pertaining to the Phoenix"

" "For the company, to get to know other fans, to get up to date info"

» "To see what others views were on the phoenix and to keep up to date with the gossip"

» "to find info. on the phoenix"

» "I love football and needed a medium to share my love for the game with like minded people,"

» "Because I supported the Phoenix from the outset and wanted to be able to express opinions with other fans"

» "To suport the phoenix

» "Because football is about supporters and singing from the terraces.

» "because $\mathrm{i}$ am a soccer nut, and i love the fact that wellington has a pro soccer team" 
» "To get behind the club - even before it had a name, or was confirmed that it was in the league."

» "Phoenix, Beer and Craziness all in that order"

» "It seemed interesting"

» "Because I was a big Phoenix fan when I lived up in Hamilton, but had no real reason to become a Fever member. Now I have shifted down to Wellington, it seemed the obvious thing to do for a football nut like me."

» "to join in with the banter and follow the news and support for the Phoenix"

» "To support the Phoenix"

» "I started Yellow Fever with the other members of the executive because (a) I knew the team would succeed or fail based on its first season so building up a supporters base was very important and (b) because it was completely different to anything that had happened to NZ football"

» "I was one of the yellow fever executive committee members, so I kind of had to."

» "Because it was the first supporters club for WPFC"

» "suppoet phoenix and nz football in general"

» "Because i am a fan of wellington phoenix and want to be kept up to date with information regarding the football club."

» "best info on the Phoenix, chance to bond with like minded people"

» "Love of wellington, football and costa barbarouses"

" "football chat"

» "i love football and wellington"

» "reader only but $\mathrm{v}$ frequent"

» "It seemed to be the natural progression from being a Nix fan to become part of the supporters club and become totally emersed in the experience."

» "to be part of it"

» "To support the Phoenix wholeheartedly"

» "To get the discounts"

» "Support the phoenix provides access to the club and members Promotes feeling of unity amongst fans"

» "to find out latest news about the Phoenix 2- to find different views on the news other than mainstream media"

» "Because it's the best way to support the Phoenix"

» "To meet fellow supporters of the Wellington Phoenix."

» "Love football. Love Wellington." 
» "to show my support and participate in all the discussion on the forums"

» "because i saw it on the news and decided to join"

» "The opportunity to be in a fan club of a local football team, after so many years of deprivation, was just too good to be passed up"

» "I support Nz football as a player, coach and teacher. But interested in further NZ football development for the future."

» "I joined Yellow Fever originally when i first heard that the site had been created right back in the early days. I wanted to show my support for a New Zealand franchise in the A-league"

» "For information sharing and support of the Wellington Phoenix."

» "BECAUSE I LOVE FOOTBALLAND LOVE THE PHOENIX"

» "Because I follow football and what the YF are doing for football in NZ is fantastic."

» "I am from Bonnie Scotland and love my footy!"

» "To get involved in the Phoenix community"

» "Because of the great atmosphere they bring to the matches, even on TV. There's nothing like it in New Zealand. I live in Christchurch however have decided I'm going to travel for every match."

» "It's good to discuss football with other NZers, especially since it doesn't get much media coverage, and isn't usually topical at work etc."

» "Stupidity. Previously a member of the 'active' support for the Kingz and the Knights, having an A-League side in Wellington made it a whole lot easier."

» "Its a great supporters club! Gets behind the team."

» "Tought the Phoenix was brilliant and Yellow Fever were there from the start"

» "wanted to keep up to date with phoenix news"

» "because i love football and wil take almost any opportunity to talk about it"

» "To support the team, share and gain information from fellow supporters and talk to like minded people. It is also a way to feel more connected to the club as the CEO, Tony Pignata, posts regularly.”

» "To have fun and make some noise; because they're a more enthusiastic bunch of supporters than any other in NZ."

» "To show support for the nix"

» "To support the team and keep up to date with information."

» "wanted to be part of something special with a pro football team in wgtn"

» "To keep up to date with Phoenix news."

» "We were excited about Wellington having a professional football team, checked 
out the Yellow Fever site, then decided to join as there seemed to be heaps of dedicated, like-minded people involved. As well as it being a very professional website"

» "because i wanted to comment on the forum"

\section{What is the single best thing about the Yellow Fever website?}

» "many things but up to minute football news a biggie, then being able to discuss or see points of view relating to the news being discussed in the forums."

» "update news about local / national / international football"

» "The forum"

» "Contact with other members and getting the blood boiling for upcoming season

» "updates so regurly with all relevant phoenix news"

» "The website is a good source of timely information. Often developments in the ALeague appear on the website earlier than official media releases."

» "comeradery"

» "Reading opinions"

» "The forum."

» "The people who contribute to it."

»"The forum"

» "It's the best source for news on the 'Nix and everyone is pretty helpful"

» "The discussions with other fans"

» "The forums. Well run, easy touse and lots to talk about."

» "reading other peoples opinions on the forum"

» "up to date information on most things football in new zealand mostly the wellington phoenix"

» "great source of information"

» "Forums"

»"Ummmmm...."

» "Its activity, a lot of forums come and go but the YF website is strong even through the off season."

" "the chat between fans, the pooling of ideas"

» "Keeing up to date with news and what other fans think."

» "Member banter !!! It's brilliant !!" 
» "The news section. The forum is good too when it's interesting,"

» "The stories on not just the Phoenix, but other A-League clubs and also New Zealand footbal.."

$»$ "me...."

» "Forums"

» "Interacting and meeting with other NZ football fans, there have just been so few opportunities for this in the past"

» "the banter on the forums"

» "Forums"

» "topics, knowing things first. getting to know other fans...talking about somethng we all feel passionately about"

» "Hearing what other fan's think of recent news about wellington phoenix"

» "lively discussions, up to date info"

» "Access to news from the a-league, the phoenix and new zealand football in general the people"

» "news and info"

» "the forum plus news"

» "It brings together everything I need as a Nix supporter, up to the minute news (links to the club so news announcements get to us quick plus links to stories from other sources as well), entertaining forums and event news all in the one place. Great bunch of guys too (oops, that's 2 sorry)"

" "up to date info"

» "Constant updates and regular posting on all topics to do with football"

» "the up to date info, always omething new to read"

» "Accessiblity to information about the club and fans"

» "Forum"

» "the forum."

»'The forum."

» "The forums. Especially the transfer gossip."

» "the regional football forum"

» "the forum"

» "The pooling of reports from many different sources accross the web"

» "The number of people who are passionate about NZ football and I could express other football development ideas for the future. I was not getting the some local $\mathrm{NZ}$ football feedback anywhere else on other football forums on the net because 
they are oversea forums."

» "The Phoenix news and banter"

»"The Forums"

» "The information you gain. Wouldn't know half the stuff about the phoenix if wasn't for the site."

»"Up to date news"

» "The variety of relevant Phoenix info that is updated before media releases.

» "Community

» "Spam United :). Although the fact that everyone is so supportive and there is little negativity on the site is great as well.

» 'its banter, jokes, sense of comraderie etc

" "The forums

» "The forum

$»$ "Forum

» "it's so up to date. Space to talk about all things football in the forum ie player's form, all whites etc

» "Sense of unified community from various backgrounds, age groups and other various demographics

» "the sense of a football community in wellington and $\mathrm{nz}$

» "The friendly feel. Everyone is there because of a common love - through losses and wins.

» "Phoenix and football news in one place

» "forum. transfer newws

$»$ "Forum"

» "the banter"

» Getting indepth, educated views on the phoenix.

» "The forum - 100's of topics, good moderation, really enthuastic (and funny!) contributors and heaps of banter. Also the fact that the CEO uses it to communicate with the membership is great."

» reading news as it happens

\section{Why did you become a Wellington Phoenix fan?}

» "Support wellington sporting teams generally, Phoenix, especially. 
» "i love football and i love Wellington

» "They are a different team, a different brand, from the Kingz/Knights

» "Love football

» local boys. and becaus esoccer is the best game in the world

» "I'm a serious football fan and the Wellington Phoenix have enabled me to watch live a professional football team that plays in my home city in a competition that is reasonably entertaining and enjoyable."

» "Love my city and football, was long overdue.

» "I like football \& it's a club I can call our own.

» "Always played and watched football. Knew some of the players, trained with them, and enjoyed watching a well covered football team in my home town."

» "Because it automatically became my local professional football club - something that Wellingon has never had during my time here."

» Was sick of watching rugby. Wanted a local team to support.

» "I'm a proud born and bred Wellingtonian so would support them regardless. But after the Melbourne Victory game last season I was totally hooked."

$»$ Cos the Knights went under.

» I love football and jumped at the chance at getting behing a strong wellington team.

» soccer fan and never had a club this big this close before

» "love of the game plus i'd supported the Kingz and Knights and always wanted wellington to have a team of it's own in the A-league"

» "As a football fan, football essentially being a minority sport in this country, I felt and still feel that it is important to support football in this city, be that attending Phoenix games or other football in this city"

» Beacuse of my love for the beautiful game

»Cos I'm from Wellington originally

» Because I love football and its now in my back yard.

» $\mathrm{i}$ love wellington and i love soccer, $\mathrm{i}$ was always going to become a fan

¿ Love football, wanted a local team to support.

$»$ Because I am Welly till I die !!!

» Michael Ferrante is a fox! Plus my boyfriend got me going along to a game and I loved it and have gone when I can since.

» "Because I love football, and I would always support a New Zealand based team (I'm also a fan of the Warriors, Breakers, and any other similar teams). Shifting down to Wellington was a nice coincidince" 
I love football

» I support anything cool coming to Wellington

» "I have done and will always support anything to do with soccer in NZ. Plus they are in my home town and the opportunity to watch live football of that level had never presented itself before. Plus I am proud to be a wellingtonian"

» A chance to support a professional football team based in Wellington

» Becasue I've always loved football, and come from Wellington

$»$ cos i love football and atmosphere of live games.

» "Because $\mathrm{i}$ like the club and i am a new zealander living in Australia and they are the only club in the a league who i feel i can truely support."

$\gg$ sick of rugby

» Love of wellington, football and costa barbarouses

$»$ football

$»$ to surrport local football

» only pro $\mathrm{nz}$ team and trying to do better than kingz etc

» "Been a football fan as long as I can remember and have been to a handful of professional games in different countries around the world. The football "experience" and atmosphere is second-to-none so when a pro club was formed in my home town there was no question that I would be a fan"

$»$ love football

» "Because I have always wanted to support a professional football team in my home town! Only Kiwi team in league"

$»$ to support Wellington sport

» "Long affinity with football, have supported a british club team my whole life however they are not very accessible over here eg. attending games, up to date information, watching games ect. The Wellingotn phoenix are the first $\mathrm{nz}$ team competing in australia that have been proffessional, recruited well, identified with their fans and most of all competed, this along with the fact they are accessible - it was a no brainer to become a supported"

» Professional football at my doorstep!

» Local football club. I like football.

» "It is Wellington's own professional football club, HATE rugby. Wellington now has a progfessional football team. 'Nuff said."

» $\mathrm{i}$ love football and to have our own team here in wellington is brilliant because $\mathrm{i}$ love wellington and because i wanted something new."

» "I have never had a major football team in a town I have lived in for more than a few months, and my father has enthused devereal times how great it was to be a 
Leeds fan in the 1960s and 1970s. I wanted to have a team of my own I couold actually go and watch."

» "Should support the professional footbal team and Wellington Phoenix are the only thing in NZ"

» "Because i wanted to support a New Zealand franchise and i really liked what was going on at the club"

» "Cos I love football and to have a professional team created on our doorstep is a dream come true!!"

» Because i love football and the atmosphere

» Only NZ proffessional team after the Knights collapsed

$\gg$ Refer to answer 1

» I support any Wellington sports team

» "Because there the only pro team in NZ, They have great supporters and they play an attractive brand of football."

» "because i love football, i live in wellington an I think it's great to have a good football team to support in my home town"

» "New Zealand football is always number one, and the Phoenix are a major part of that."

» Becuase finally we have a team to support down here! Wellington is the home of football

» Professional Football

» because i like football and they are good to watch unlike the knights

» To support a Profesional, local football team

» because good football in NZ is a gift from above

»As soon as it was announced they were entering the A-League in place of the New Zealand Knights.

»Excitement of seeing the team play live at home.

$»$ just did

»Im a sports fan, it was natural

» love football and supported both Kingz and knights

» To support the beautiful game in New Zealand

» "Love football - my husband is English and I lived there for a number of years. Fantasic camaradirie amongst footie fans which was bourne out during the season because they were in town and its great to see football grow" 


\section{What is the single best thing about being a Wellington Phoenix fan?}

» "Being part of something Extraordinary,right from the beginning right here in Wellington "Watching decent football in the best city in the world. ***I would go to every game but i live in London"

» Supporting the team all th

» Top quality sport in the city for once

» Pride in the team no matter what!

$\gg$ See answer to question 5.

» the passion for the game and the phoenix.

$\gg$ Wellington pride.

» "Get to watch and enjoy professional football with a team to support and be passionate about."

» Match day.

» The sense of comradeship.

» Being part of the atmosphere and crowd at the Ring of Fire

» That we have a NZ football team to support

» "Having something to look forward to every weekend and knowing that for 2 hours a week you can just forget about everything else."

$»$ the atmosphere at the games

$\gg$ the wellington phoenix

» the crowd atmospere is better than any other sporting event I've ever been to

» Supporting the team and chanting at the opposition players

» Being back in Welly to support them

» "Having a local footy club to support, watching all the rugby-heads drop scathing comments because they're jealous."

» being a fan of nz greatest pro sport team!

» going to the match.

» Seing my Boy (my self included) go absolutely mental when the Nix score a goal !!!!!

» Watching the football. :)

» "Being in the same city as them, getting to actually be a part of the club and fan base, not like if it was a European team" 
» Supporting a local team

» Being in the crowd shouting when they score a goal

» Watching live A-League football in my home town

» atmosphere at games

» Having a professionally based footbal team in my home town

» watching and winning

» "Knowing that your team will put heart and soul into the game they are playing and will never give up."

» "bonding together with like minded people, its fun, the games are lively and entertaining and the atmosphere is brilliant, best sports atmosphere in NZ sport"

» The pride, the passion and the emotion

$»$ RICKI!

$»$ being apart of yellow fever crew

$\gg$ no single thing

» "The atmosphere and being part of a loud and vocal group of supporters for what looks like becoming a pretty good professional football club."

$»$ local professional team

» Seeing quality football in Wellington

$»$ having a professional team to fully support

$\gg$ excitement

» "belonging to a club that has a good relationship with its fans and that sets good standards on and off the field"

„ Following the team through ups and downs, the management is great.

» Watching them play and beat the Aussies.

» Having a team that is truly yours to support.

» "Everything. Wellington is wonderful. The stadium is wonderful. Football is wonderful. Phoenix till I die."

$\gg$ the prestige!

$\gg$ being passionate

» "A feeling of actual belonging to a team that means something to me, Leeds United are great, but having never lived in Leeds they seem too distant to get too involved in"

» The yellow fever members and the number of good developments to football in general.

» Yellow Fever... 
» Singing in the Fever Zone on match days

» The Atmosphere

» The atmosphere

» The fantastic atmosphere at the stadium

» Best fan experience in the world

» Being a part of the great supporters.

$\gg$ it's not rugby

» The feeling that I live in a football city.

» The crowd at the games

$\gg$ Shirts off.

» "everyone's right in behind them, they're competitive, there are many kiwis in the team, good coach, exciting to watch (good style)"

» Going to the backbencher and singing before the game

» "the feeling of the Nix scoring at the Ring of fire and being among thousands of other football nutters when it happens"

» "The emotions you go through during a match. Also, when you're at the game, sharing those emotions with the people around you. For better or for worse."

»Excitement of seeing the team play live at home.

$»$ fun

» The camaraderie and being part of something built up from nothing from the very start.

» watching pro football

» Being a fan of the only Kiwi team in an Aussie competition (and winning).

» having a team that's 'ours', standing in the yellow fever zone supporting them.

» the atmosphere, 90 minutes 90 emotions 